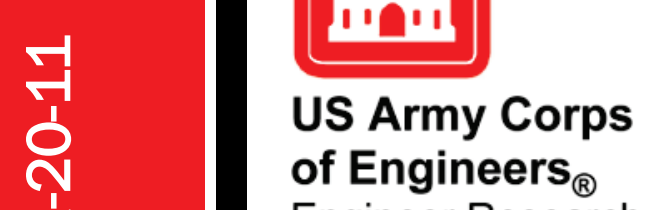

\title{
WERDC
}

Engineer Research and

Development Center

Risk Assessment Planning and Tools for OpeRations (RAPTOR)

\section{Projecting Changes in Food Security Throughout Central America}

Kayla A. Cotterman, Aaron C. Petri, James D.

May 2020

Westervelt, and Angela M. Rhodes

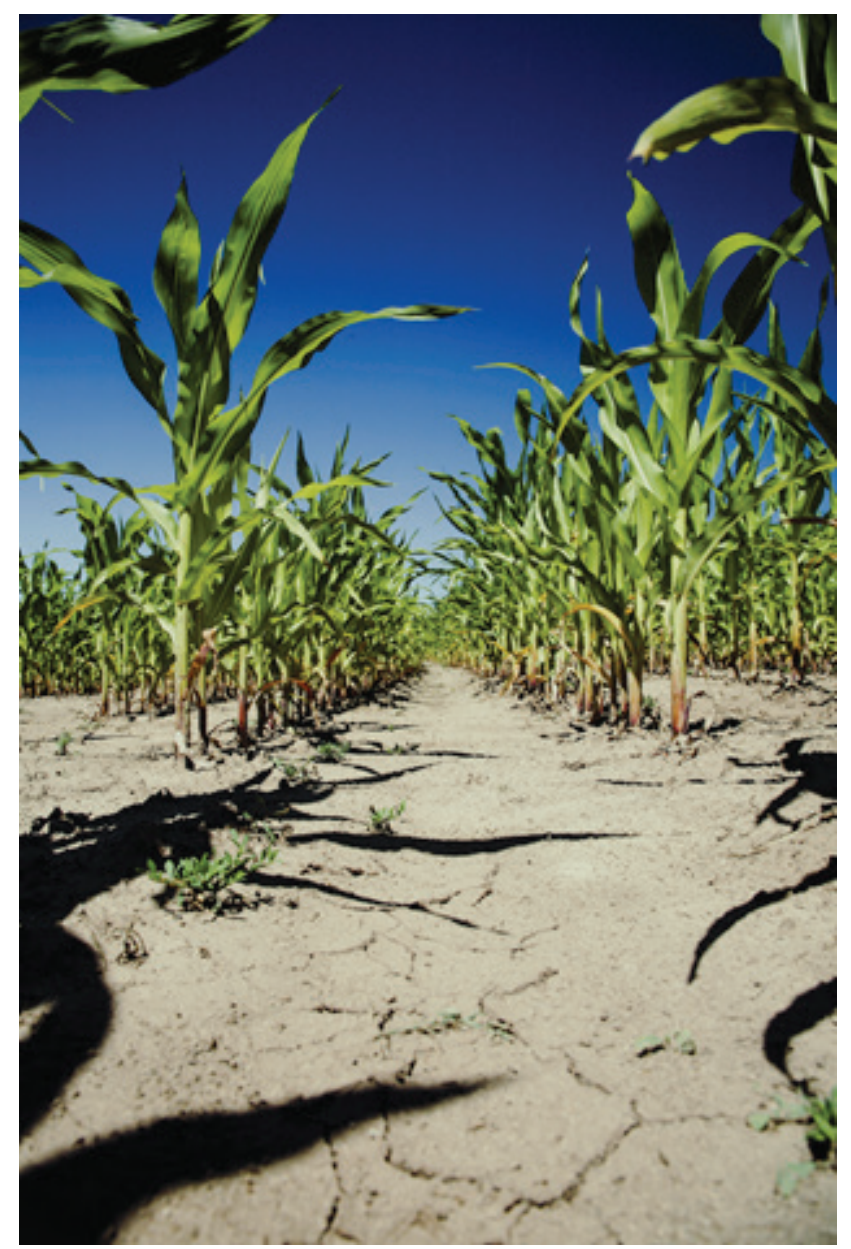


The U.S. Army Engineer Research and Development Center (ERDC) solves the nation's toughest engineering and environmental challenges. ERDC develops innovative solutions in civil and military engineering, geospatial sciences, water resources, and environmental sciences for the Army, the Department of Defense, civilian agencies, and our nation's public good. Find out more at www.erdc.usace.army.mil.

To search for other technical reports published by ERDC, visit the ERDC online library at http://acwc.sdp.sirsi.net/client/default. 


\title{
Projecting Changes in Food Security Throughout Central America
}

\author{
Kayla A. Cotterman \\ Coastal and Hydraulics Laboratory \\ U.S. Army Engineer Research and Development Center \\ 3090 Halls Ferry Rd. \\ Vicksburg, MS 39066 \\ Aaron C. Petri, James D. Westervelt, and Angela M. Rhodes \\ Construction Engineering Research Laboratory \\ U.S. Army Engineer Research and Development Center \\ 2902 Newmark Drive \\ Champaign, IL 61822
}

Final Technical Report (TR)

Approved for public release; distribution is unlimited.

Prepared for Headquarters, U.S. Army South

Fort Sam Houston, Texas 78234

Under FAD 2040-19/20-40, "Risk Assessment Planning and Tools for Operations"

(RAPTOR), Project No. 477345-T222, "Human Geography” 


\section{Abstract}

Climate non-stationarity continues to change the productivity of local food and water supply. These changes in supplies could result in starvation or surpluses, greatly affecting the surrounding populations and causing adverse effects such as malnutrition, mass migration, and political unrest. This study addresses the following questions regarding the future potential of land resources to support local populations with food and water: How will crop production be affected by changing environmental conditions? Which specific regions are expected to experience the greatest pressure? How might we expect land use to shift through the end of the 21st century, based on future environmental conditions? Current crop growth is analyzed, along with projected crop growth based on future climate scenarios. Recent historic anthropogenic biome maps are statistically correlated with recent historic climate data to generate models and are applied to anticipated future climates to generate future anthrome maps. The crop analysis is then coupled with the anthromes results, yielding a crop suitability forecast. This analysis is constrained to the area of Central America over the course of the 21st century.

DISCLAIMER: The contents of this report are not to be used for advertising, publication, or promotional purposes. Citation of trade names does not constitute an official endorsement or approval of the use of such commercial products. All product names and trademarks cited are the property of their respective owners. The findings of this report are not to be construed as an official Department of the Army position unless so designated by other authorized documents.

DESTROY THIS REPORT WHEN NO LONGER NEEDED. DO NOT RETURN IT TO THE ORIGINATOR. 


\section{Contents}

Abstract ......................................................................................................................................... if

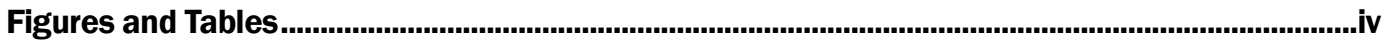

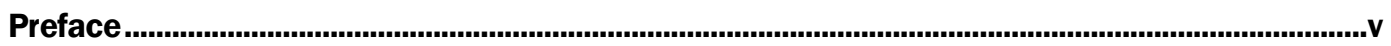

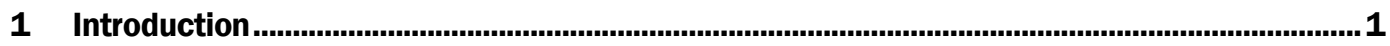

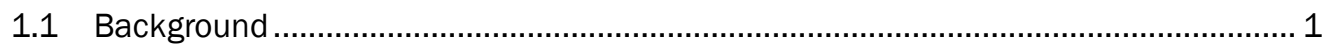

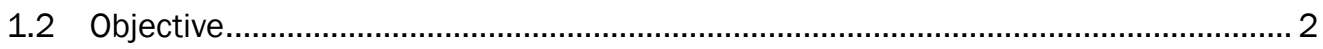

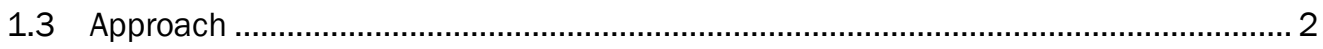

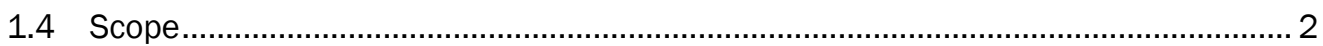

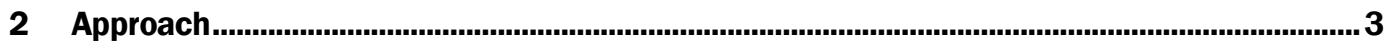

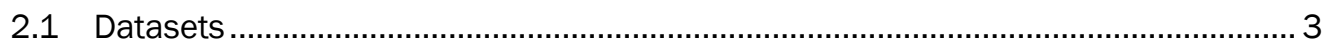

2.1.1 Food and Agriculture Organization (FAO) ................................................................. 4

2.1.2 Global Agro-Ecological Zones (GAEZ) Inputs............................................................ 4

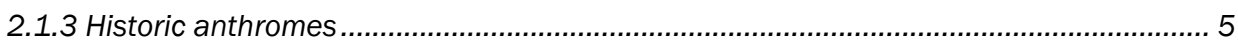

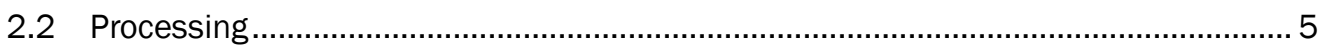

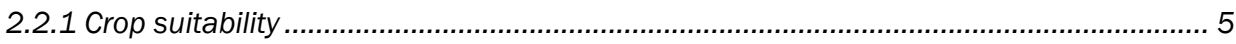

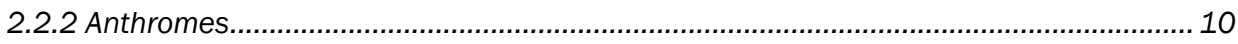

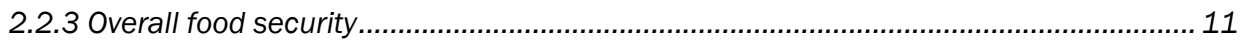

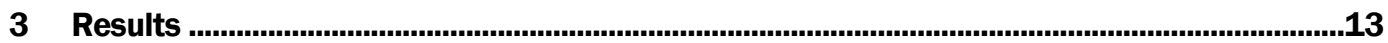

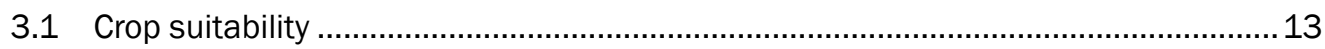

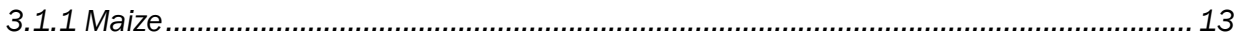

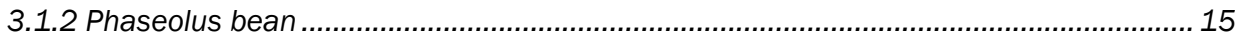

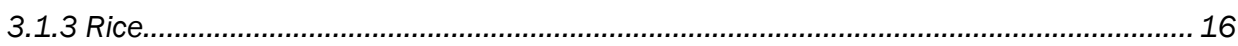

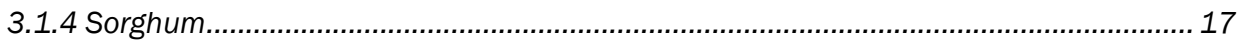

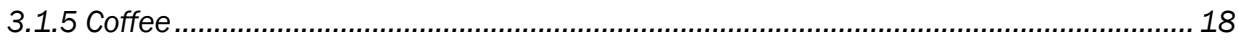

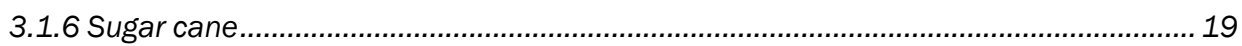

3.2 Human settlement and land use ...................................................................... 20

3.2.1 Rainfed villages - villages dominated by rainfed agriculture ......................................21

3.2.2 Residential rainfed croplands - rainfed cropland with substantial human

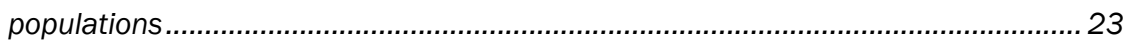

3.2.3 Residential rangelands - rangelands with livestock grazing and minimal forests and crops with substantial human populations........................................... 24

3.2.4 Residential woodlands - forests with substantial human populations .........................2 24

3.2.5 Populated woodlands - forests with minor human populations ................................... 25

3.3 Combined crop suitability and human settlement.............................................25

4 Discussion and Conclusions .............................................................................................29

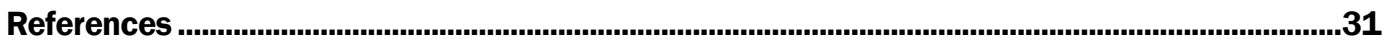

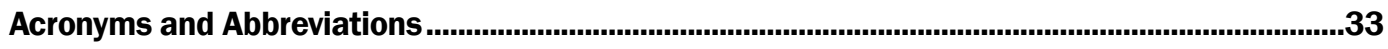

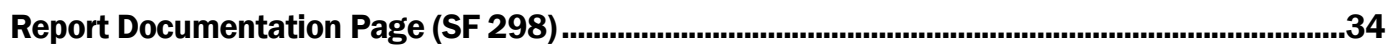




\section{Figures and Tables}

\section{Figures}

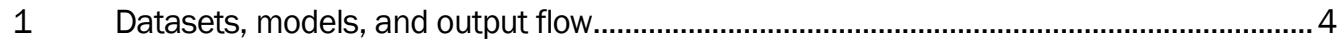

2 Maize suitability change predicted by the four models under scenario A2 ........................ 8

3 Maize suitability baseline data for the historic time period ............................................... 9

$4 \quad$ Overall predicted change from the four GCMs regarding maize. Note that the scale represents the amount of agreement between models ...........................................14

5 Overall predicted change from the four GCMs regarding production of phaseolus bean. Note that the scale represents the amount of agreement between models ........15

6 Overall predicted change from the four GCMs regarding production of rice. Note that the scale represents the amount of agreement between models ...

7 Overall predicted change from the four GCMs regarding production of sorghum. Note that the scale represents the amount of agreement between models

8 Overall predicted change from the four GCMs regarding production of coffee. Note that the scale represents the amount of agreement between models ...................18

9 Overall predicted change from the four GCMs regarding production of sugar cane. Note that the scale represents the amount of agreement between models ........19

10 Future projection of anthromes for the historic time period and each GCM of interest for the 2080s

11 Overall projected change in land suitability from the four GCMs under scenario A2. Note that the scale represents the amount of agreement between models ............26

12 Historic anthromes (A) compared to future projection of majority anthrome per pixel (B).

\section{Tables}

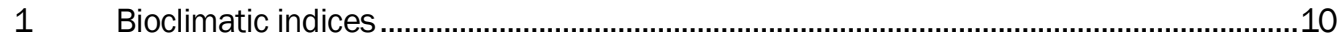

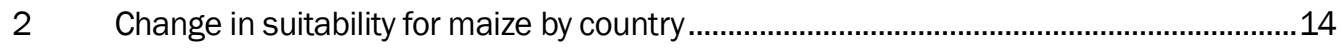

$3 \quad$ Change in suitability for phaseolus bean by country .......................................................16

$4 \quad$ Change in suitability for rice by country .......................................................................

$5 \quad$ Change in suitability for sorghum by country ...............................................................18

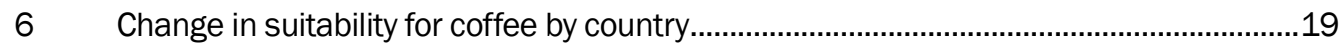

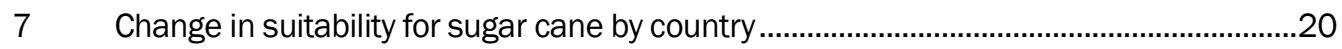

$8 \quad$ Change in suitability for all crops by country ...............................................................20

9 Historic and future percent ranges and calculated percent decrease of rainfed villages.............................................................................................................................23

10 Historic and future percent ranges and calculated percent decrease of residential rainfed croplands............................................................................................2

11 Historic and future percent ranges and calculated percent decrease of residential rangelands......................................................................................................2

12 Historic and future percent ranges and calculated percent decrease of residential woodlands .......................................................................................................25

13 Historic and future percent ranges and calculated percent decrease of populated woodlands 


\section{Preface}

This study was conducted for the U.S. Army South under Funding Authorization Document (FAD) 2040-19/20-40, "Risk Assessment Planning and Tools for Operations" (RAPTOR), Project No. 477345-T222, "Human Geography." The technical monitor was Angela Rhodes.

This work was performed by the Hydrologic Systems Branch, of the Flood and Stream Protection Division, U.S. Army Engineer Research and Development Center, Coastal and Hydraulics Laboratory (ERDC-CHL); and the Environmental Processes Branch, of the Installations Division, U.S. Army Engineer Research and Development Center, Construction Engineering Research Laboratory (ERDC-CERL). At the time of publication, Dr. HwaiPing Cheng was Chief of the Hydrologic Systems Branch and Dr. Cary Talbot was Chief of the Flood and Stream Protection Division. Mr. Jed Alvey was Chief of the Environmental Processes Branch and Ms. Michelle Hanson was Chief of the Installations Division. The Program Manager was Angela Rhodes and the Technical Director was Ritchie Rodebaugh. The Director of ERDC-CHL was Dr. Ty Wamsley and the Acting Director of ERDC-CERL was Dr. Kumar Topudurti.

COL Teresa A. Schlosser was Commander of ERDC, and Dr. David W. Pittman was the Director. 
THIS PAGE INTENTIONALLY LEFT BLANK 


\section{Introduction}

\subsection{Background}

Water is one of the key elements that enable society to survive. Ancient civilizations were often settled near water since water itself is essential for life, and nearby bodies of water were conduits for easier transportation. Over time, water engineering practices were developed to increase the usability of local water. Sanitation systems in cities reduced waterborne diseases, advanced irrigation systems watered crops, and increased crop yield.

Humans have established their culture and livelihood in direct response to local precipitation and temperature patterns; this is the driving force for local food production. Ellis and Ramankutty (2008) classified these settlements into a series of anthropogenic biomes, i.e., "anthromes," or human-dominated biomes. Climate non-stationarity affects water availability and the suitability of land for food production. This results in a shift of anthromes and the humans, flora, and fauna that define them to other areas better suited for survival.

The growing global human population (now approaching 8 billion) contributes to an increased stress on the Earth's capacity to support human life. The effects of climate change stress rural areas and reduce opportunities for agricultural jobs, which leads to migration from rural to urban areas. This is particularly important in largely agrarian geographic areas, especially in regions where food is produced primarily for local consumption. This shift in climate, when coupled with human migration, creates changes in food productivity and in local food and water supplies that can result in surpluses or shortages, even starvation. These conditions may also require the agrarian population to adapt by learning how to cultivate specialty crops that are more suitable to the changed climate and water availability.

The Army's global peacekeeping mission often involves anticipating possible sources of conflict. Water and food availability represent complex security threats that can contribute additional stress in areas already facing political unrest. An analysis of food security in stressed areas could provide enough advanced warning of such conflict drivers to avoid or otherwise effectively and efficiently deal with the potential trajectory to future conflict. 
This work was undertaken to evaluate food security in Central America, specifically Belize, Guatemala, Honduras, El Salvador, and Nicaragua. The information outlined may be useful for gaining an understanding of potential changes in the Central America region related to food production including shifts to anthropologically-relevant biomes.

\subsection{Objective}

The objective of this work was to evaluate the future potential of food security across Central America and the ability of this region to continue to support local populations with food and water. Specifically, this work sought to address these questions:

- How will crop production be affected by changing environmental conditions?

- Which specific regions are expected to experience the greatest pressure?

- How might we expect land use to shift through the end of the 21st century, based on future environmental conditions?

\subsection{Approach}

This work used the Food and Agriculture Organization (FAO) of the United Nations Global Agro-ecological zones (GAEZ) methodology for assessing future suitability of six highly popular crops in Central America: maize, rice, sorghum, phaseolus bean, coffee, and sugar cane. The GAEZ model incorporates several factors to determine crop growth suitability based on soils, terrain, climate, precipitation, current land use, and current crop yields. The projection maps are compared to a baseline map to establish overall change.

Recent historic anthrome maps were statistically correlated with recent historic climate data to generate models that were then applied to anticipated climate to project future anthrome locations. These future anthrome maps were evaluated and summarized to suggest how the future climate may affect land use. The crop projection maps were then compared with the future anthromes maps to determine impacts to human populations.

\subsection{Scope}

This analysis is limited to the area of Central America over the course of the 21st century based on the results of recent climate models. 


\section{Approach}

The chapter outlines the steps used to conduct a food security analysis in Central America. The analysis considers both changing crop suitability coupled with changing anthromes, to determine potential locations of push factors for migration from rural areas.

In this analysis, we combine two distinct approaches. In the first approach, we assess the ways in which projected environmental characteristics could influence the crop production of specific crops grown in Central America. In the second approach, we determine how projected environmental characteristics could influence the way people settle and use the land in the future. The results are then compared side by side to consider potential impacts to human populations.

\subsection{Datasets}

The following datasets were used in the analysis and are explained below. Figure 1 outlines the data inputs, models for analysis, and output results. The arrows that point to each box outline how the flow of the analysis occurred. The left hand side of Figure 1 outlines the steps for the crop suitability analysis while the right hand side shows the anthrome analysis.

The boxes in red are data inputs required for the analysis. To determine the crop type to analyze, the FAO dataset was required to determine crop growth by acreage for each country; while this was not a direct input into the model, it was necessary to determine which crops to analyze. The yellow boxes are the analysis boxes; they receive inputs (red) and output future projection maps (green). The green boxes are the individual crop suitability map projections and the future anthrome projections. These green boxes feed into the blue boxes that outline the analysis to determine an overall projection for crop suitability and anthromes. Purple boxes represent the comparison between historic and future projections for both crop suitability and anthromes. Crop suitability is represented by one map showing the change from historic suitability to future projection of suitability. Since anthromes maps are classified by anthrome type and not a scale, the change in future anthrome analysis is represented by two maps: one representing historic anthromes and one representing the most frequently occurring anthrome among the future projections. 
Figure 1. Datasets, models, and output flow.

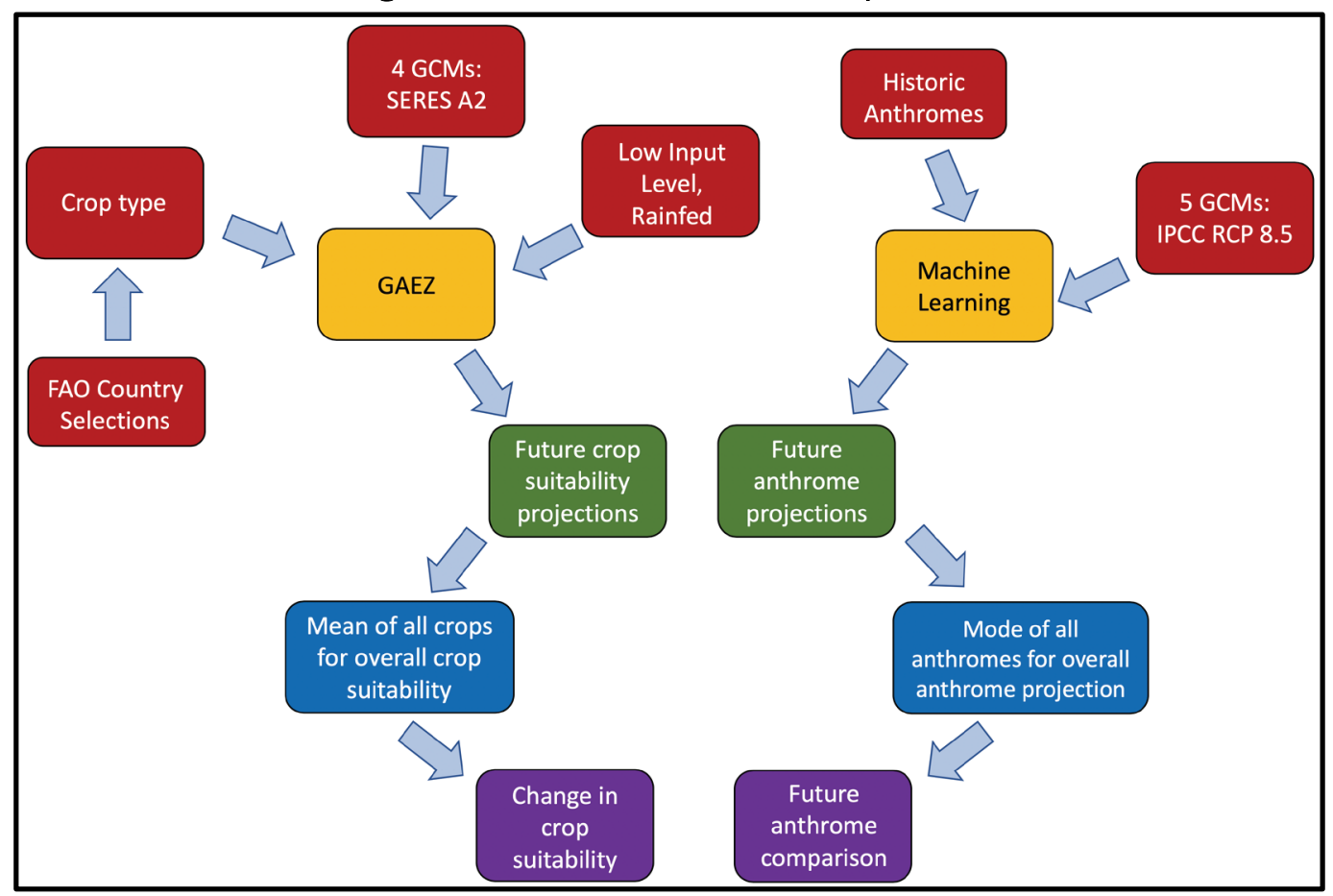

\subsubsection{Food and Agriculture Organization (FAO)}

The FAO has gathered data on numerous aspects relating to food and agriculture. FAO data were used to determine crop growth per country (FAO 2017). This process examined crops by country of interest. The countries considered in this study were Belize, Guatemala, Honduras, El Salvador, and Nicaragua. Once the countries were identified, all of the crops available were chosen and were sorted by area harvested; this allowed us to sort the crops spatially from the most populous to the least populous. From here, the data were downloaded in comma-separated values (CSV) format allowing for easy sorting.

\subsubsection{Global agro-ecological zones (GAEZ) inputs}

The FAO along with the International Institute for Applied Systems Analysis (IIASA) collaborated in developing the GAEZ dataset (IIASA/FAO 2012). The GAEZ portal was used to download the data of interest. This interactive data retrieval system allows the user to focus on parameters of interest such as crop type, climate, and management strategy. The results are aggregated for current, major land use patterns. The portal allows for both easy visualization and download options. 
The data consist of five main thematic areas:

1. land resources

2. agro-climatic resources

3. suitability and potential yield

4. actual yield and production

5. yield and production gaps.

This study focused on the suitability and potential yield area. Within the GAEZ portal, the necessary parameters for GAEZ output were selected including crop type, water supply, input level, climate scenario, and time period of interest.

\subsubsection{Historic anthromes}

Historic locations of anthromes were completed by work done by Ellis and Ramankutty (2008). The anthromes are based on biomes, which ecologists use to define global patterns of biodiversity and ecosystems. However, anthromes are slightly different as they include the biodiversity coupled with how humans interact with the ecosystem thus yielding "anthropogenic biomes" that shorten to anthromes. This historic anthrome map was used to train the model by examining current bioclimatic indices associated with current anthromes. The data are available in four different formats: Environmental Systems Research Institute, Inc. (ESRI) Binary GRID, GeoTIFF, ARC/INFO ASCII GRID, and NetCDF (Network Common Data Form) Raster, all at a resolution of 5 arc minute.

\subsection{Processing}

\subsubsection{Crop suitability}

One of the greatest challenges that a society faces is the ability to provide adequate nutrition to the ever-growing population. Changing land use coupled with climate non-stationarity creates issues regarding land suitability for crop growth. This is particularly important in geographic areas that exhibit largely agrarian lifestyles and those where food is produced for local consumption. Globally, annual cereal crop demand is likely to increase by approximately $46 \%$ by 2050 (Alexandratos and Bruinsma 2012). However, if current crop management continues into the future, changes in climate are likely to reduce crop yields (Asseng et al. 2015, Bassu et al. 2015). A decrease in crop suitability leading to a food shortage could lead 
to security risks such as mass migration, which is often coupled with an area experiencing political turmoil.

Crop data were collected from the FAO (IIASA/FAO 2012). Using the FAO crop database for 2014, the top 10 crops types based on land area were selected for each country. Based on the top 10 crop types per country, six total crop types were chosen for this study. These crops were chosen because they were in the top 10 of harvested area for at least of three of the five countries of interest. These crops include maize, rice, sorghum, phaseolus bean, coffee, and sugar cane.

The analysis relies on the FAO GAEZ methodology for assessing agricultural resources and production potential to determine crop suitability. The GAEZ data portal was developed between the Land and Water Division of the Natural Resources Management and Environmental Department of FAO to ensure that partnership countries have access to reliable information in regard to food and agriculture in support of policy decisions. Therefore, the authors did not have any input into the model validation or calibration process.

The GAEZ model uses data downscaled from two emission scenarios and four Global Circulation Models (GCMs). The GAEZ web site provides crop projection data for four different GCMs. For these GCMs there are two scenarios from the Special Report on Emissions Scenarios (SRES) (Bernstein et al. 2000) common to all models: A2 and B2. The SRES are based on a set of assumptions regarding how the world is projected to function from the perspective of emissions in the future. The A2 scenario consists of a heterogeneous world favoring regional change with high population growth and energy usage. Land use changes are medium to high with medium amount of Gross Domestic Product (GDP) growth. Future resource availability is low with pace and directions of technological growth slow. However, the B2 scenario is based on dynamics as usual, with medium growth and change across all platforms including population, GDP, energy use, land use change, resource availability, and pace and direction of technology (Bernstein et al. 2000). Since the A2 dataset is more aggressive compared to B2, it was chosen for this analysis; it assumes that population continues to increase with slower economic growth and technological change, therefore presenting a more pronounced "worst-case" scenario. The A2 scenario assumes more energy-intensive, carbon-based processes, with correspondingly greater Greenhouse Gas (GHG) emissions (Bernstein et al. 2008). The 
$\mathrm{CO}_{2}$ emissions associated with this scenario are the highest of all four scenario families. Additionally, the A2 scenario includes a growing population and economic development oriented by region. Newer climate scenarios are based on the Representative Concentration Pathways (RCPs). Within the $\mathrm{RCP}$ scenarios, there are four options, with RCP 8.5 being the least conservative option and therefore most similar to the A2 scenario.

This analysis used the GAEZ model to focus on changes in land suitability. The model provides predicted change in land suitability for crop production under user-specified growing conditions. The model output represents change given in currently cultivated land area. For the crops included in this study, the parameters used to run the model are (1) specific crop (i.e., maize, rice, etc.), (2) rainfed water supply (i.e., no irrigation), (3) low input level (i.e., no fertilizers or pest treatment, minimum conservation methods, etc.), and (4) no $\mathrm{CO}_{2}$ fertilization (i.e., no extra $\mathrm{CO}_{2}$ is added due to increase in $\mathrm{CO}_{2}$ from anthropogenic affects). Based on these parameters, a list of downloadable maps and tables are created.

For each crop, the GAEZ model outputs a total of five maps, one for each respective GCM for the 2080 s epoch and a historic map. An example of maize is shown in Figure 2 with the four future projections illustrating the variation in suitability predicted by the four GCMs. Note that three of the models (i.e., C2A, CS, and $\mathrm{EH}$ ) produce similar results while the fourth (i.e., $\mathrm{H}_{3} \mathrm{~A}$ ) is substantially different. While this gives us confidence in our results, it also reminds us that there is a certain amount of error in predictive models. This is also shown in the overall crop summaries. For example, if a crop has a 1 for suitability, it is the mean, which indicates that more than likely some models find that more suitable while others find it less suitable. Figure 3 shows the historic baseline map example of maize.

After the four future projections were made for each crop type, the maps were combined using Geographic Information System (GIS) software to provide an overall change map in land suitability for each crop type as shown in Figures 4 through 9 in chapter 3. Using the mean to represent an overall change considers multiple climate models yielding a more complete picture of the future. Different models perform better with different physical processes, and taking an average helps to capture aspects that may be overlooked if only one GCM were used. 
Figure 2. Maize suitability change predicted by the four models under scenario A2.

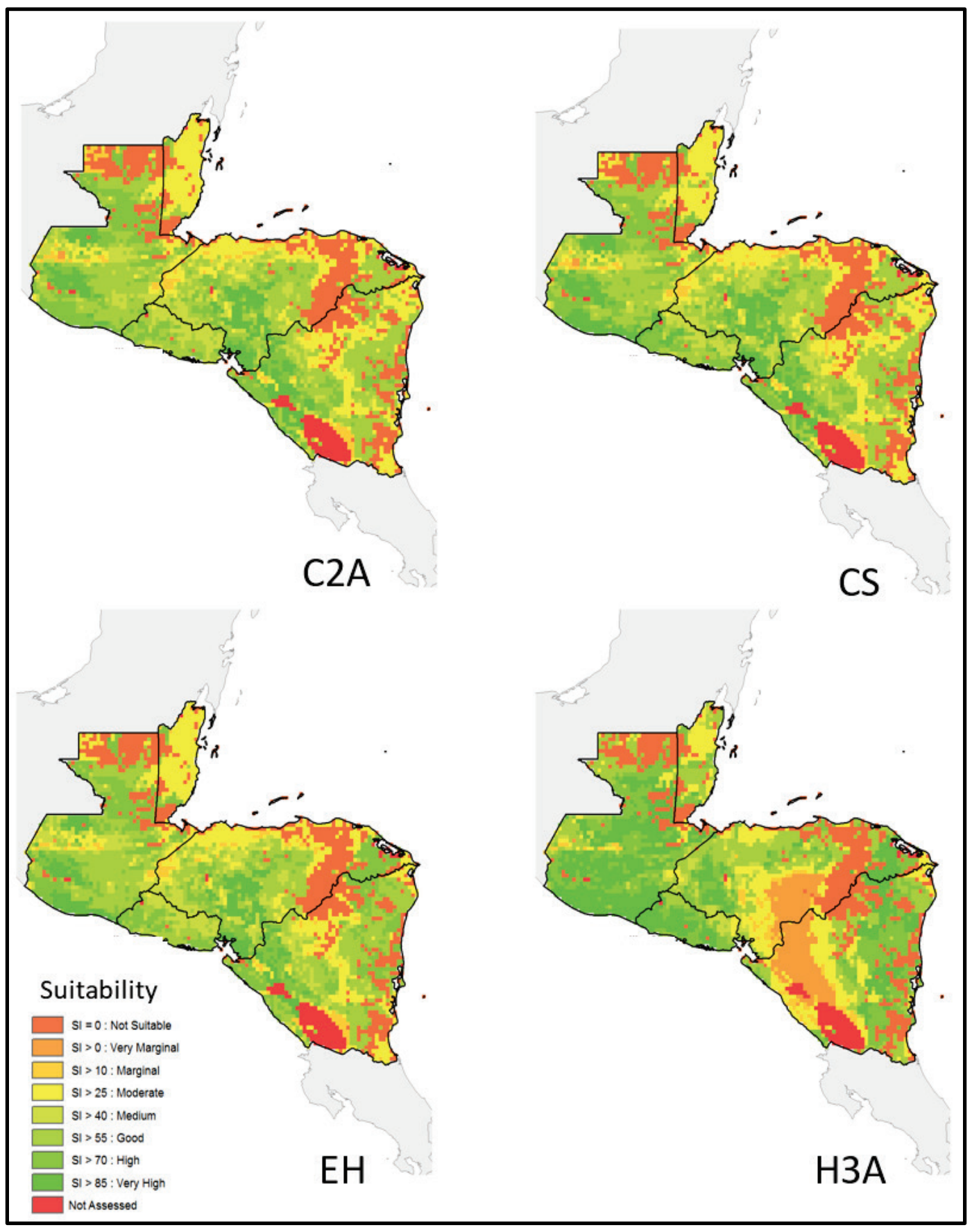


Figure 3. Maize suitability baseline data for the historic time period.

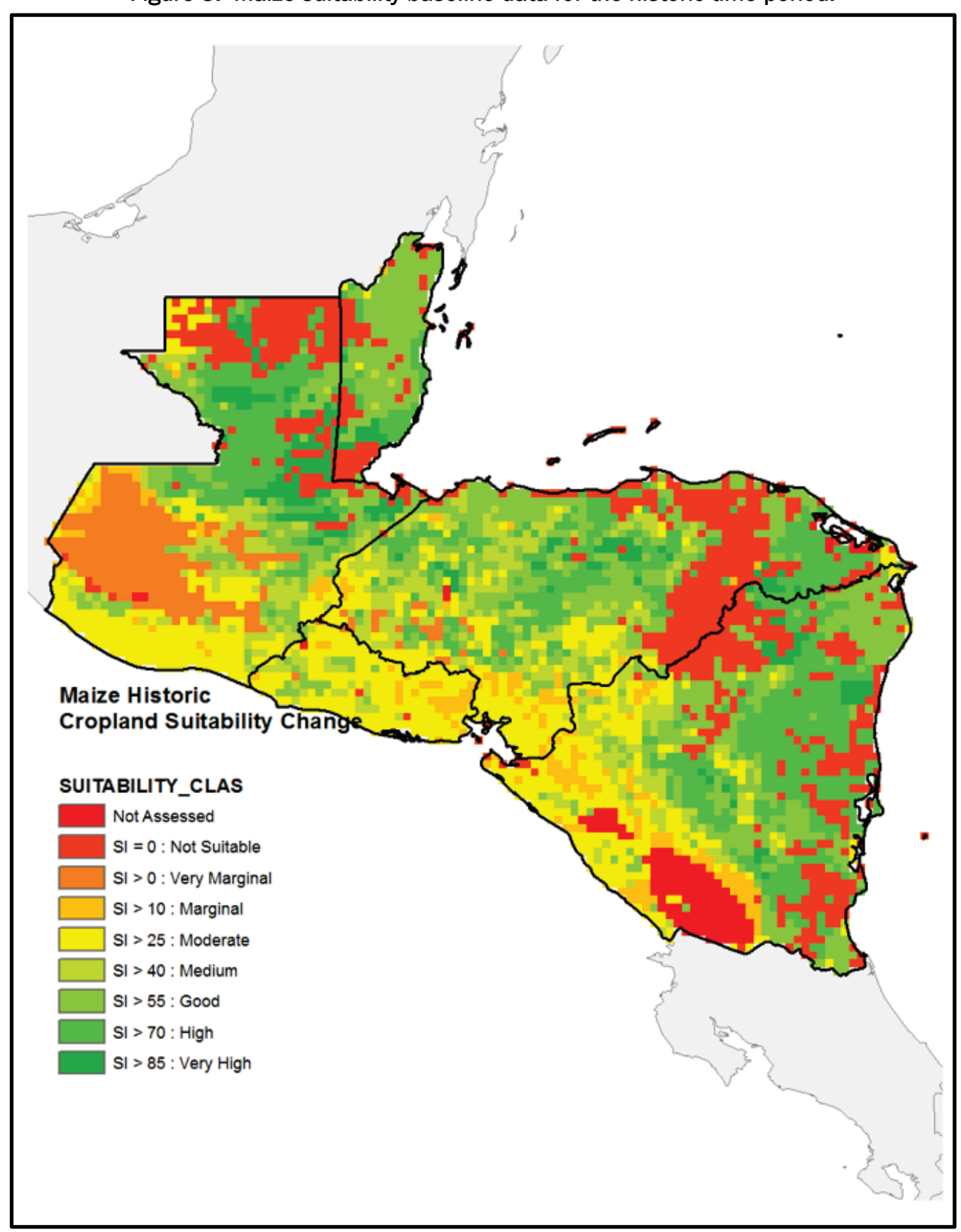

The A2 and the B2 scenarios were used as they were the only ones that were available from the GAEZ portal. For both the historic time period and future models under the A2 scenario, the red areas indicated as "Not Assessed" are water bodies. The areas that are considered "Not Suitable" are biological preserves and have been excluded from these analyses. 


\subsubsection{Anthromes}

Flora and fauna throughout the world compete with one another under different climatic conditions thus determining the location and subsequent extent of ecological systems globally. Ellis and Ramankutty (2008) adopted this idea to establish anthromes based on population, land use, land cover, and the way humans have made use of natural resources. For the anthromes analysis, we used downscaled results from Intergovernmental Panel on Climate Change (IPCC) Fifth Assessment Report from the GCM Downscaled Data Portal (Ramirez and Jarvis 2008, Jarvis 2014). The data files are at a resolution of 30 arc-seconds and include derivative results of all of the models.

First the results from climate models are converted to maximum, minimum, and mean temperature, and average rainfall by month across a time period of 10 years, which is an epoch. Additionally, the resolution of raw climate data is too large and must be downscaled to show local change, which considers specific details at the local scale regarding elevation, proximity to coastlines, and land/water. Since living things respond to parameters such as temperature and rainfall during the growing season, comparing locations across the globe at any given time of year is irrelevant due to seasonal differences. Table 1 lists 19 bioclimatic indices described by O’Donnell and Ignizio (2012) that have been adapted by landscape researchers worldwide.

Table 1. Bioclimatic indices.

\begin{tabular}{|l|l|}
\hline Index & Description \\
\hline BI01 & Annual Mean Temperature \\
\hline BI02 & Mean Diurnal Range (Mean of monthly (max temp - min temp)) \\
\hline BI03 & Isothermality (BI02/BIO7) (* 100) \\
\hline BI04 & Temperature Seasonality (standard deviation *100) \\
\hline BI05 & Max Temperature of Warmest Month \\
\hline BI06 & Min Temperature of Coldest Month \\
\hline BI07 & Temperature Annual Range (BI05-BI06) \\
\hline BI08 & Mean Temperature of Wettest Quarter \\
\hline BI09 & Mean Temperature of Driest Quarter \\
\hline BI010 & Mean Temperature of Warmest Quarter \\
\hline BI011 & Mean Temperature of Coldest Quarter \\
\hline BI012 & Annual Precipitation \\
\hline
\end{tabular}




\begin{tabular}{|c|l|}
\hline Index & Description \\
\hline BI013 & Precipitation of Wettest Month \\
\hline BI014 & Precipitation of Driest Month \\
\hline BI015 & Precipitation Seasonality (Coefficient of Variation) \\
\hline BI016 & Precipitation of Wettest Quarter \\
\hline BI017 & Precipitation of Driest Quarter \\
\hline BI018 & Precipitation of Warmest Quarter \\
\hline BI019 & Precipitation of Coldest Quarter \\
\hline
\end{tabular}

The bioclimatic index data were cropped to cover all of Central America. Then a statistical model developed using the R statistical software, was created using a random forest technique to train a classification model (Liaw and Wiener 2002). This training was based on historic bioclimatic indices and historic anthrome locations (Ellis and Ramankutty 2008). Thus, the model was able to produce projections showing where new anthromes might develop under changed climate conditions that correlated historic land use with the bioclimatic indices. The statistical model was applied to all of the climate models to produce future projection maps. If a particular land cover type was too small, it was eliminated from the analysis due to the criteria set for the statistical analysis. Within the domain, 30,000 points of interest were analyzed with 15,000 points used for model validation and 15,000 points used to train the model for future model projections.

The percentage of each anthrome type was then calculated for each country. If the anthrome had at least 10\% coverage for at least one of the GCMs for the country of interest, it was considered in the analysis. A range of percentages based on the highest and lowest GCM of each country were then determined to be the low and high range for each anthrome. The projected future percentage was compared to the historic amount, yielding a percent change. Maps and summaries of changes to anthromes under different scenarios were developed.

\subsubsection{Overall food security}

The resultant analysis of land suitability for crop production was compared with the anthrome model outputs to determine how change might influence human settlement. This analysis yields insight regarding potential migration and shifts in the type of crop produced in specific areas. Even though different sets of GCMs were used, they are comparable for 
several different reasons. In both the crop suitability and anthrome future projections, an aggregate of the future projections was taken rather than relying on one particular GCM. Examining an ensemble of GCMs reduces the impact of one specific GCM by focusing on the system in its entirety. Additionally, both cases use the "worst-case scenario" climate projection for each set of GCMs.

To see the effects of a non-stationary climate on crop suitability and anthromes, a comparison between baseline maps and future projection maps highlight areas likely to experience a change. Areas suitable for livability are highlighted showing where migration may occur.

The future projection for crop suitability combines all crops of interest. Climatic changes can affect crop suitability, which will likely affect how people use the land. Changes in land suitability may cause people to migrate to areas more suitable for growing crops and away from areas where crop growth is struggling. Water availability influences where people can irrigate and what crops are most favorable for the given water regime, thus resulting in a shift of anthrome classification. 


\section{Results}

\subsection{Crop suitability}

The first part of this analysis is focused on future crop suitability, which indicates whether the land use is suitable for growing a specific crop such as maize. For all crop suitability figures, the -4 designation represents agreement between all four models that land will become more suitable for the crop of interest in the future, and the 4 designation represents agreement between all four models that land will become less suitable. Zero represents "no change" and almost exclusively represents lands that are not currently cropped or are biological preserves. Zero can also mean that two models show an increase and two show a decrease; there is not a strong agreement among the models one way or another. The range between -4 and 0 , and between $o$ and 4 represents the range of agreement/disagreement between GCMs that change in crop suitability will improve or worsen.

\subsubsection{Maize}

Maize production is expected to remain steady or slightly increase in the future based on land suitability (Figure 4). In general, the moderately suitable land in Belize, Guatemala, and El Salvador becomes more favorable with a very small portion worsening. In Honduras and Nicaragua, the land area where conditions become more favorable is approximately equivalent to the land area that decreases in suitability. The analysis shows that a loss in suitability primarily occurs in central Honduras and the western edge of Nicaragua. This decline is balanced by improved suitability on the north and easterly portions of these two countries. Belize experiences $\sim 30 \% \mathrm{im}-$ provement in suitable land area where it is not currently considered suitable for production of maize. The percentage of improvement is determined by comparing the GAEZ model summary statistics of projected suitability to the baseline data. Table 2 outlines the overall change predicted by the four GCMs for maize. 
Figure 4. Overall predicted change from the four GCMs regarding maize. Note that the scale represents the amount of agreement between models.

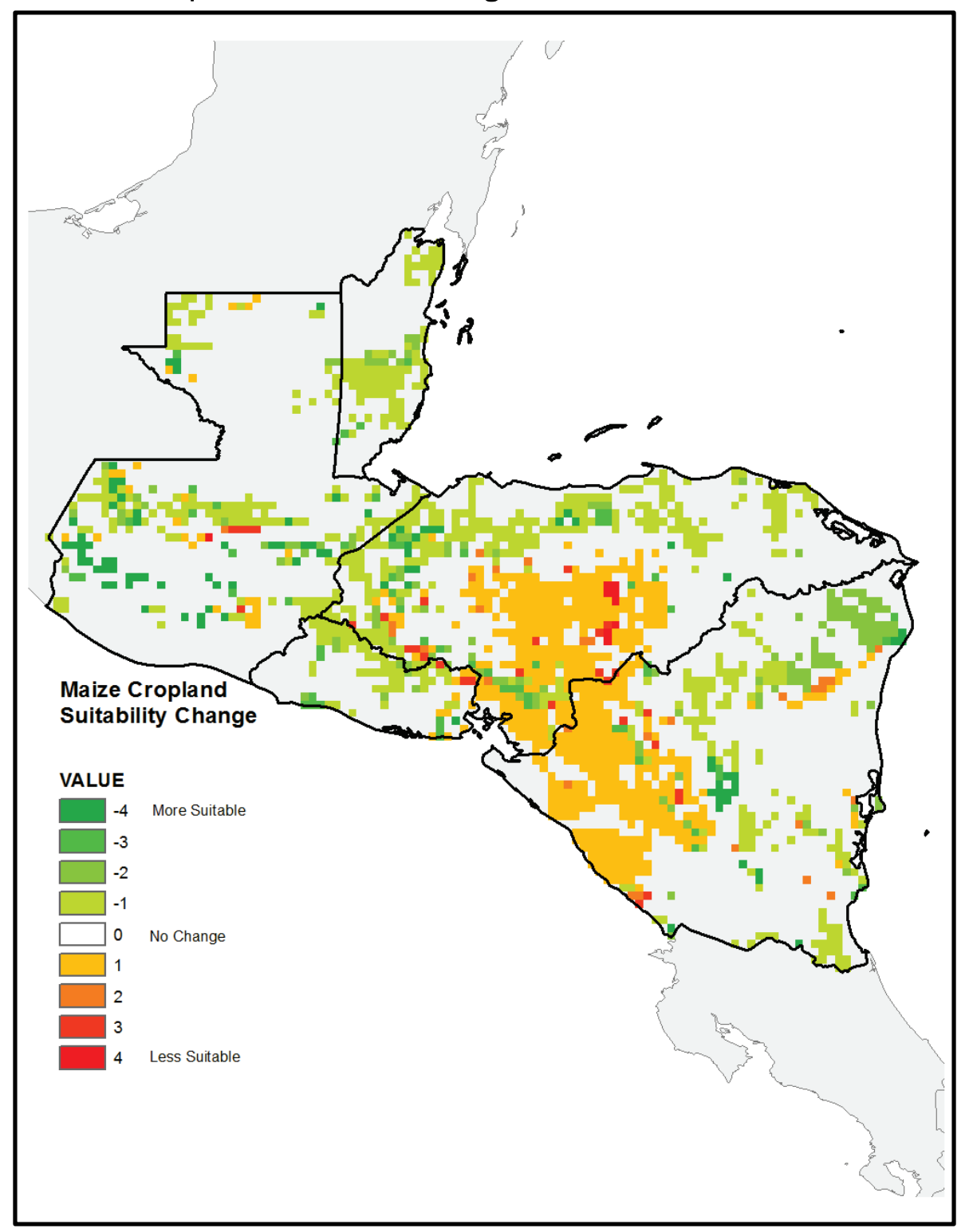

Table 2. Change in suitability for maize by country.

\begin{tabular}{|l|c|c|}
\hline Country & Percent Better & Percent Worse \\
\hline Belize & 32 & 0 \\
\hline El Salvador & 28 & 6 \\
\hline Guatemala & 18 & 2 \\
\hline Honduras & 22 & 23 \\
\hline Nicaragua & 16 & 20 \\
\hline Overall & 20 & 14 \\
\hline
\end{tabular}




\subsubsection{Phaseolus bean}

Phaseolus bean is representative of multiple types of bean crops commonly grown as foodstuffs (Figure 5). Land suitability for beans becomes overall more favorable for each country in the future except for El Salvador, which shows a slight overall loss. The shift in suitability is like that of maize - the moderately suitable land in each country becomes more suitable whereas some of the currently suitable land becomes less suitable. The analysis shows that loss in suitability primarily occurs in central Honduras and the western edge of Nicaragua. This decline is balanced by improved suitability of lands to the north and east within these two countries. Belize experiences a $\sim 30 \%$ improvement in suitability, whereas it is not currently considered suitable for the production of beans. Table 3 shows the overall change predicted by the four GCMs.

Figure 5. Overall predicted change from the four GCMs regarding production of phaseolus bean. Note that the scale represents the amount of agreement between models.

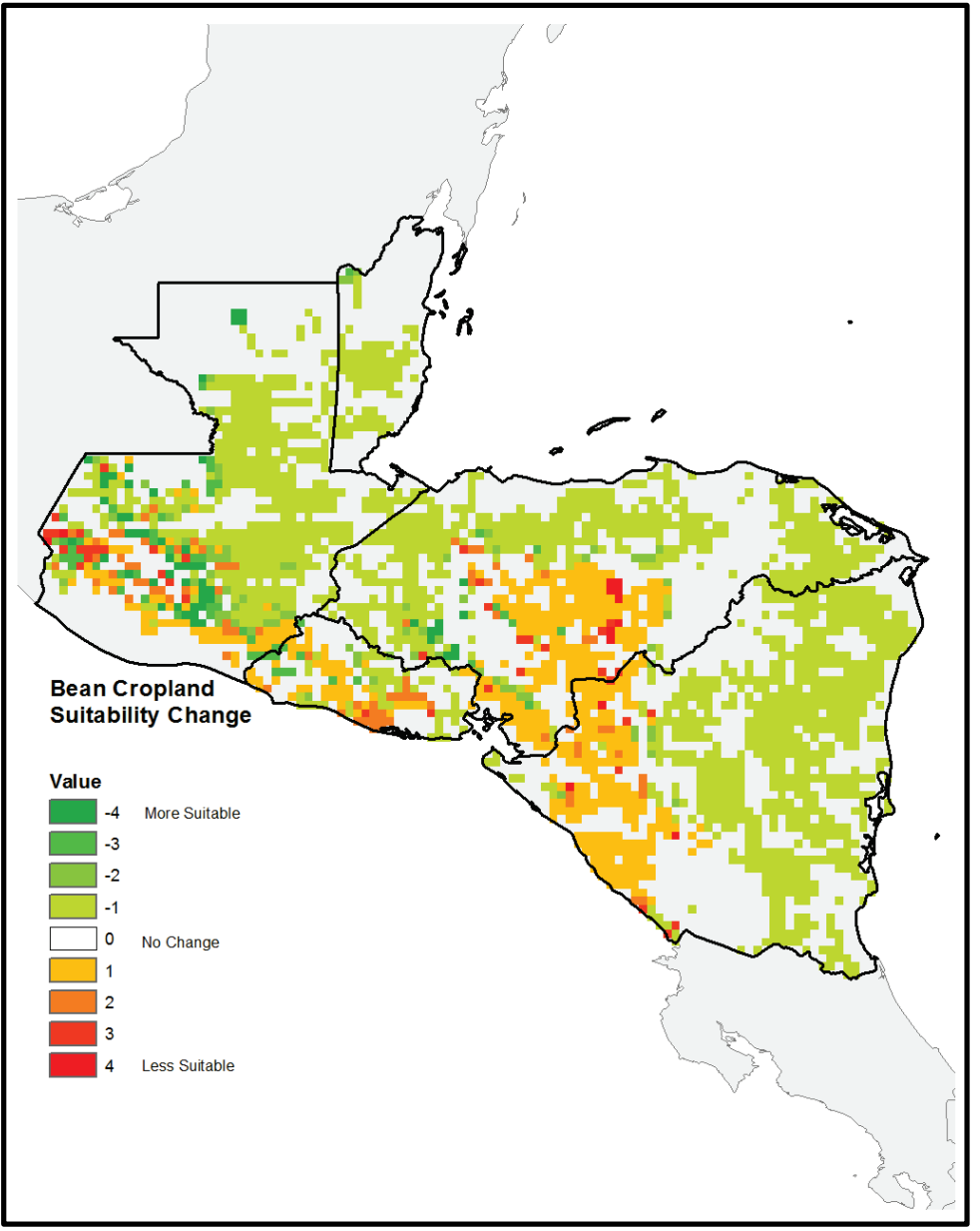


Table 3. Change in suitability for phaseolus bean by country.

\begin{tabular}{|l|c|c|}
\hline Country & Percent Better & Percent Worse \\
\hline Belize & 31 & 0 \\
\hline El Salvador & 25 & 30 \\
\hline Guatemala & 40 & 9 \\
\hline Honduras & 35 & 18 \\
\hline Nicaragua & 42 & 13 \\
\hline Overall & 38 & 13 \\
\hline
\end{tabular}

\subsubsection{Rice}

The suitability of land for production of rice in the future worsens for each country over the study period (Figure 6). Overall, the loss in area suitable for rice production is concentrated to large swaths of land in Guatemala, Honduras, and Nicaragua. Additionally, a sizable portion of land to the north edge of Belize becomes less suitable. Table 4 illustrates the overall change predicted by the four GCMs.

Figure 6. Overall predicted change from the four GCMs regarding production of rice. Note that the scale represents the amount of agreement between models.

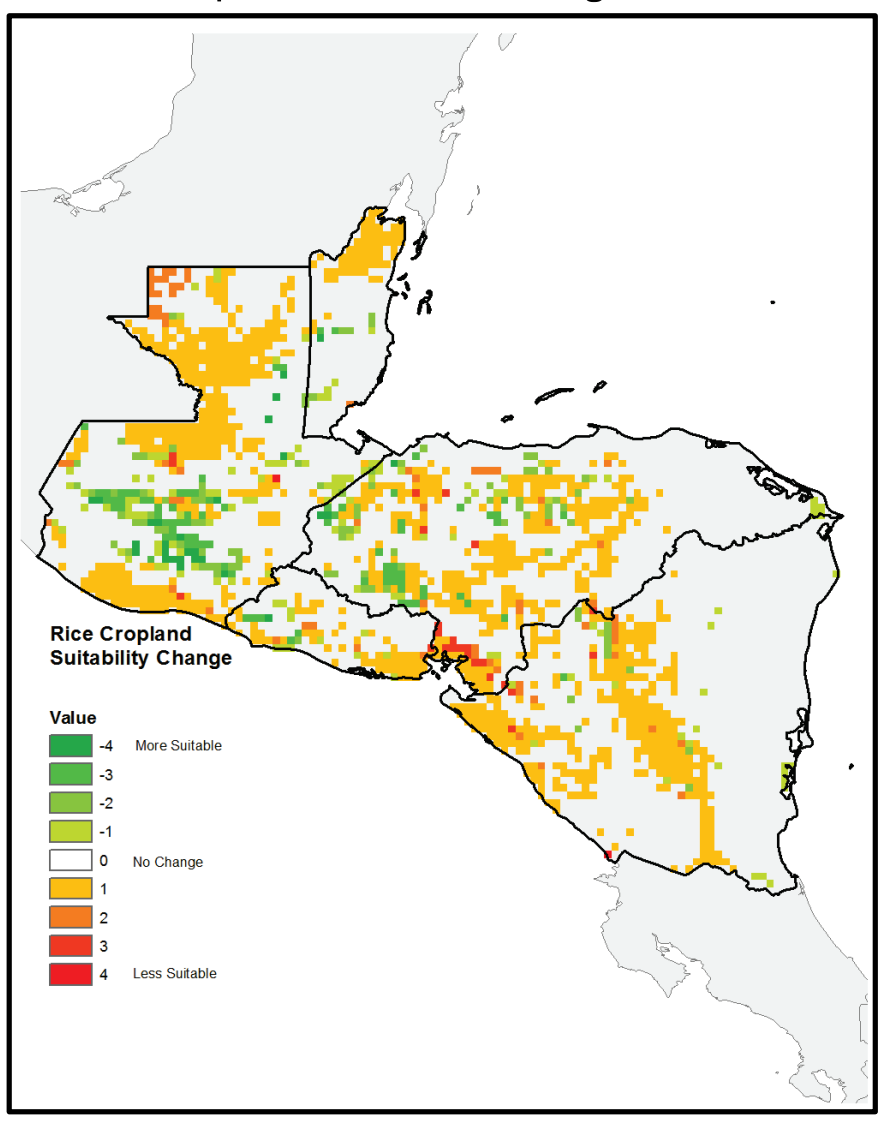


Table 4. Change in suitability for rice by country.

\begin{tabular}{|l|c|c|}
\hline Country & Percent Better & Percent Worse \\
\hline Belize & 6 & 21 \\
\hline El Salvador & 8 & 27 \\
\hline Guatemala & 13 & 30 \\
\hline Honduras & 8 & 25 \\
\hline Nicaragua & 2 & 21 \\
\hline Overall & 7 & 25 \\
\hline
\end{tabular}

\subsubsection{Sorghum}

The analysis indicates that the condition of land for production of sorghum significantly improves for all countries (Figure 7). The land area that is currently considered moderate-marginally suited is expected to improve. The most substantial decline in suitability occurs in central Honduras, west Nicaragua, and south-central Guatemala. These are areas that are currently considered good to very suitable for sorghum production. Table 5 shows the overall change predicted by the four GCMs.

Figure 7. Overall predicted change from the four GCMs regarding production of sorghum. Note that the scale represents the amount of agreement between models.

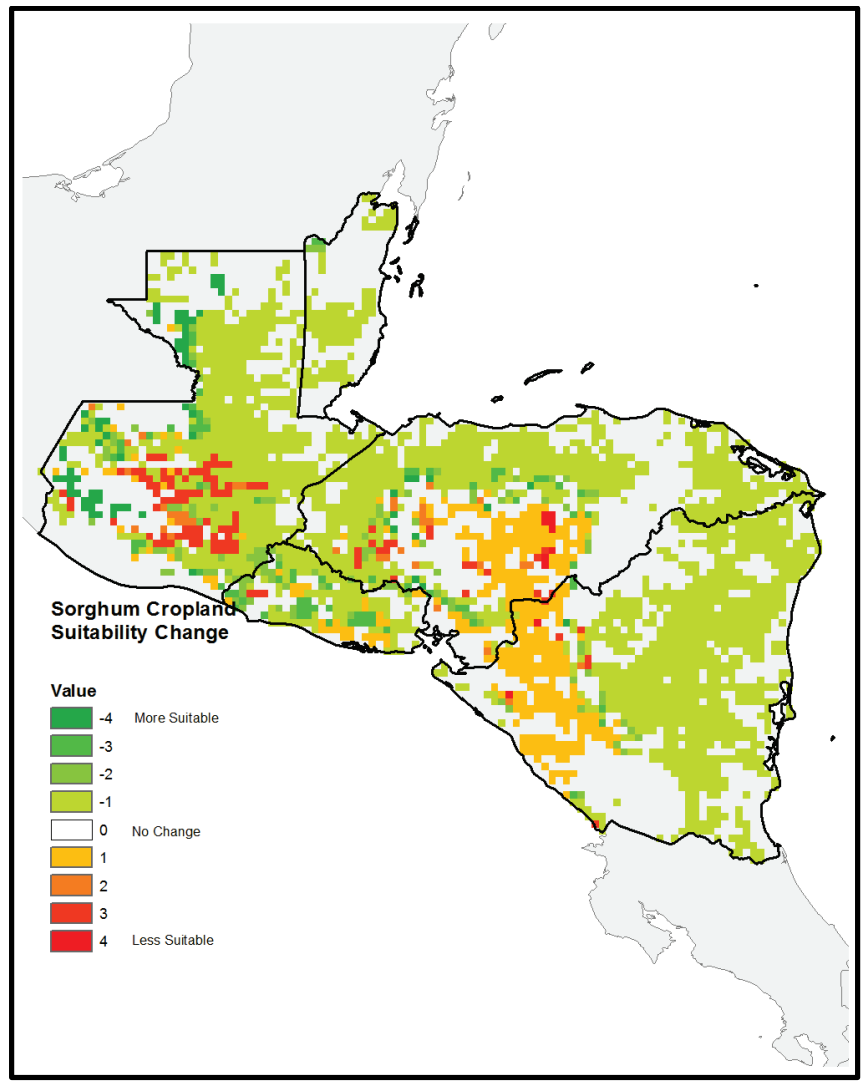


Table 5. Change in suitability for sorghum by country.

\begin{tabular}{|l|c|c|}
\hline Country & Percent Better & Percent Worse \\
\hline Belize & 36 & 0 \\
\hline El Salvador & 59 & 13 \\
\hline Guatemala & 49 & 9 \\
\hline Honduras & 43 & 15 \\
\hline Nicaragua & 49 & 12 \\
\hline Overall & 47 & 11 \\
\hline
\end{tabular}

\subsubsection{Coffee}

Land suitability for production of coffee is expected to considerably worsen over the study period for all countries (Figure 8). Nearly all land area that is currently considered suitable is expected to become less suitable for production of coffee. Table 6 shows the overall change predicted by the four GCMs.

Figure 8. Overall predicted change from the four GCMs regarding production of coffee. Note that the scale represents the amount of agreement between models.

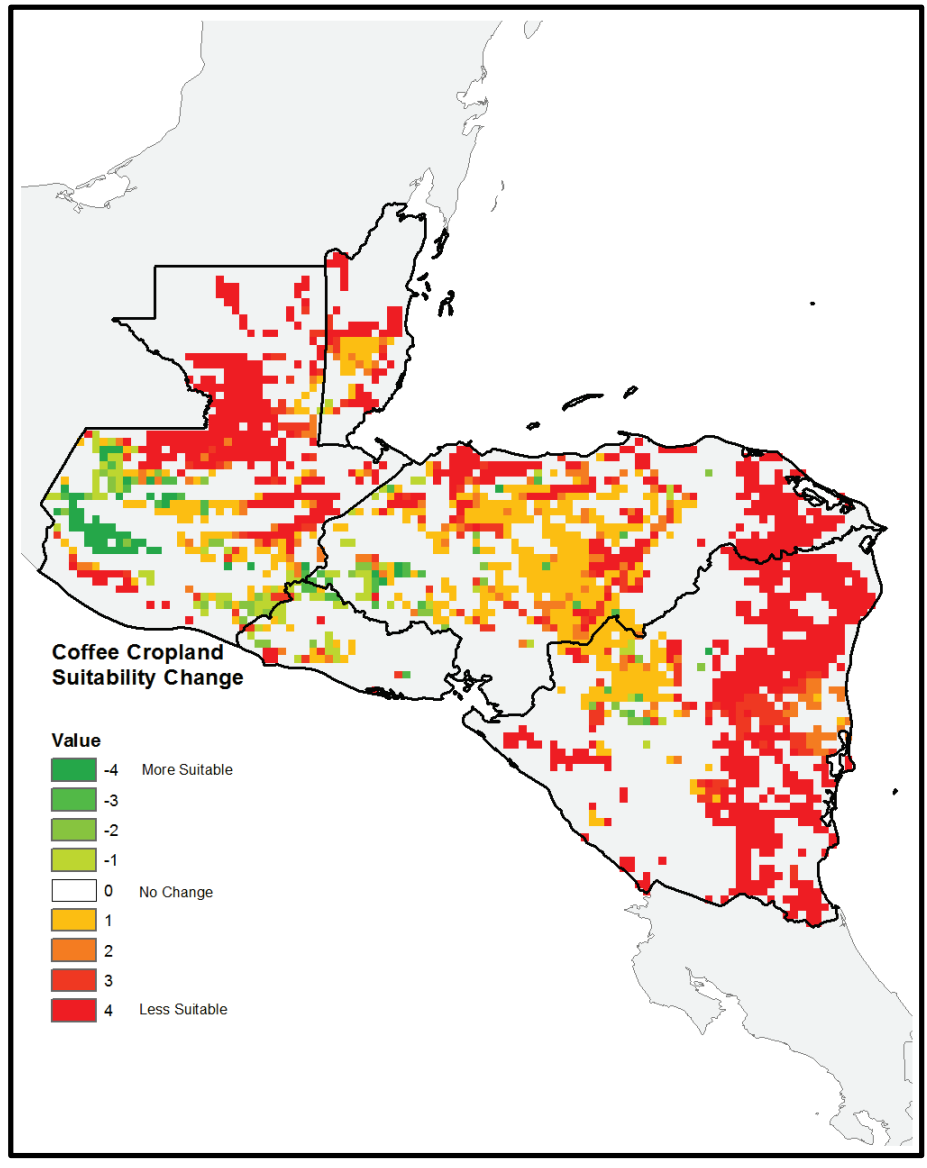


Table 6. Change in suitability for coffee by country.

\begin{tabular}{|l|c|c|}
\hline Country & Percent Better & Percent Worse \\
\hline Belize & 1 & 29 \\
\hline El Salvador & 10 & 10 \\
\hline Guatemala & 9 & 31 \\
\hline Honduras & 4 & 41 \\
\hline Nicaragua & 1 & 42 \\
\hline Overall & 5 & 36 \\
\hline
\end{tabular}

\subsubsection{Sugar cane}

Land suitability for production of sugar cane is expected to worsen over the study period for all countries (Figure 9). Nearly all land area that is currently considered suitable is expected to become unsuitable for production of sugar cane except for the eastern edge of Nicaragua. Table 7 shows the overall change predicted by the four GCMs.

Figure 9. Overall predicted change from the four GCMs regarding production of sugar cane. Note that the scale represents the amount of agreement between models.

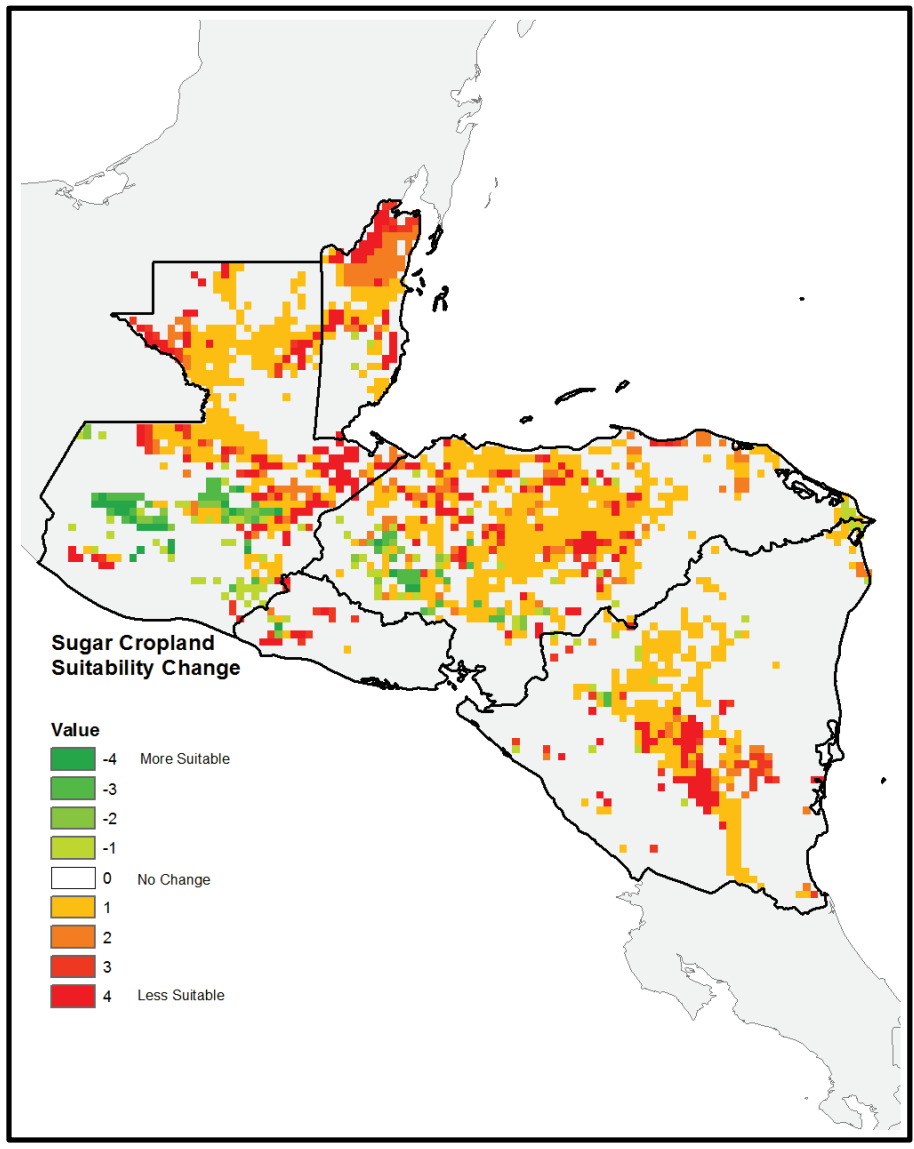


Table 7. Change in suitability for sugar cane by country.

\begin{tabular}{|l|c|c|}
\hline Country & Percent Better & Percent Worse \\
\hline Belize & 1 & 50 \\
\hline El Salvador & 2 & 8 \\
\hline Guatemala & 8 & 29 \\
\hline Honduras & 5 & 39 \\
\hline Nicaragua & 1 & 20 \\
\hline Overall & 4 & 29 \\
\hline
\end{tabular}

Table 8 shows the change of suitability for all crops for each country as well as the entire domain. The values are calculated by comparing the summary statistics from the GAEZ projected change in suitability for the GCM to the baseline data, also from GAEZ. Overall, crop suitability decreases for all of the countries in the region. This is likely due to future climates having an increase in temperature, which creates a higher stress on water resources for the crops due to higher evapotranspiration rates and change in growing season. Results vary depending on the GCM used, some exhibit decreasing future precipitation amounts while others exhibit increasing amounts. This causes a wide range in possible crop suitability that could be potentially devastating if low rainfall is coupled with high temperatures.

Table 8. Change in suitability for all crops by country.

\begin{tabular}{|l|c|c|}
\hline Country & Percent Better & Percent Worse \\
\hline Belize & 1 & 50 \\
\hline El Salvador & 2 & 8 \\
\hline Guatemala & 8 & 29 \\
\hline Honduras & 5 & 39 \\
\hline Nicaragua & 1 & 20 \\
\hline Overall & 4 & 29 \\
\hline
\end{tabular}

\subsection{BHuman settlement and land use}

Rather than analyzing biomes, which focus solely on differences between vegetation types, we examine anthromes, which also explores the human impact on land use and land cover patterns (Ellis and Ramankutty 2008, Martin et al. 2014). Known anthromes can be associated with bioclimatic indices resulting from historic global climate data; projected changes in bioclimatic indices can help project how anthromes will likely shift under varying climate regimes in the future. Therefore, this analysis recognizes 
that future climates could create different pressures in Central America that could potentially shift human land use patterns.

This analysis examined RCP 8.5 during the 2080s epoch (Figure 10) historic anthromes were compared to future anthromes to show which areas would likely remain with the same anthromes in the future and which areas would likely differ under different GCMs. For an anthrome to be examined, at least $10 \%$ of the country must be covered with the anthrome of interest in at least one of the GCMs. Percent changes were calculated comparing historic values to each of the future GCMs.

Percent ranges and percent change ranges are given based on the highest and lowest GCM for each country of the anthromes of interest. Descriptions of anthromes are based on descriptions from Ellis and Ramankutty (2008). Note that the last column in the table is percent decrease; therefore, if a value has a negative sign (i.e., indicating negative decrease), it is actually a percent increase.

\subsubsection{Rainfed villages - villages dominated by rainfed agriculture}

Compared to historic values at $19 \%$, Guatemala remained very close its past values for the 2080 opoch at $15 \%$ with a decrease of about $4 \%$. Belize had no rainfed villages for the historic period but is projected to have between $\mathrm{O}$ and $25 \%$ in the future. Contrarily, El Salvador has a decrease from historic values of $55 \%$ to a range of $4 \%$ to $30 \%$ for the future yielding a decrease to $25 \%$ to $51 \%$. Table 9 summarizes the percent ranges of rainfed villages of the five countries analyzed in this study. 


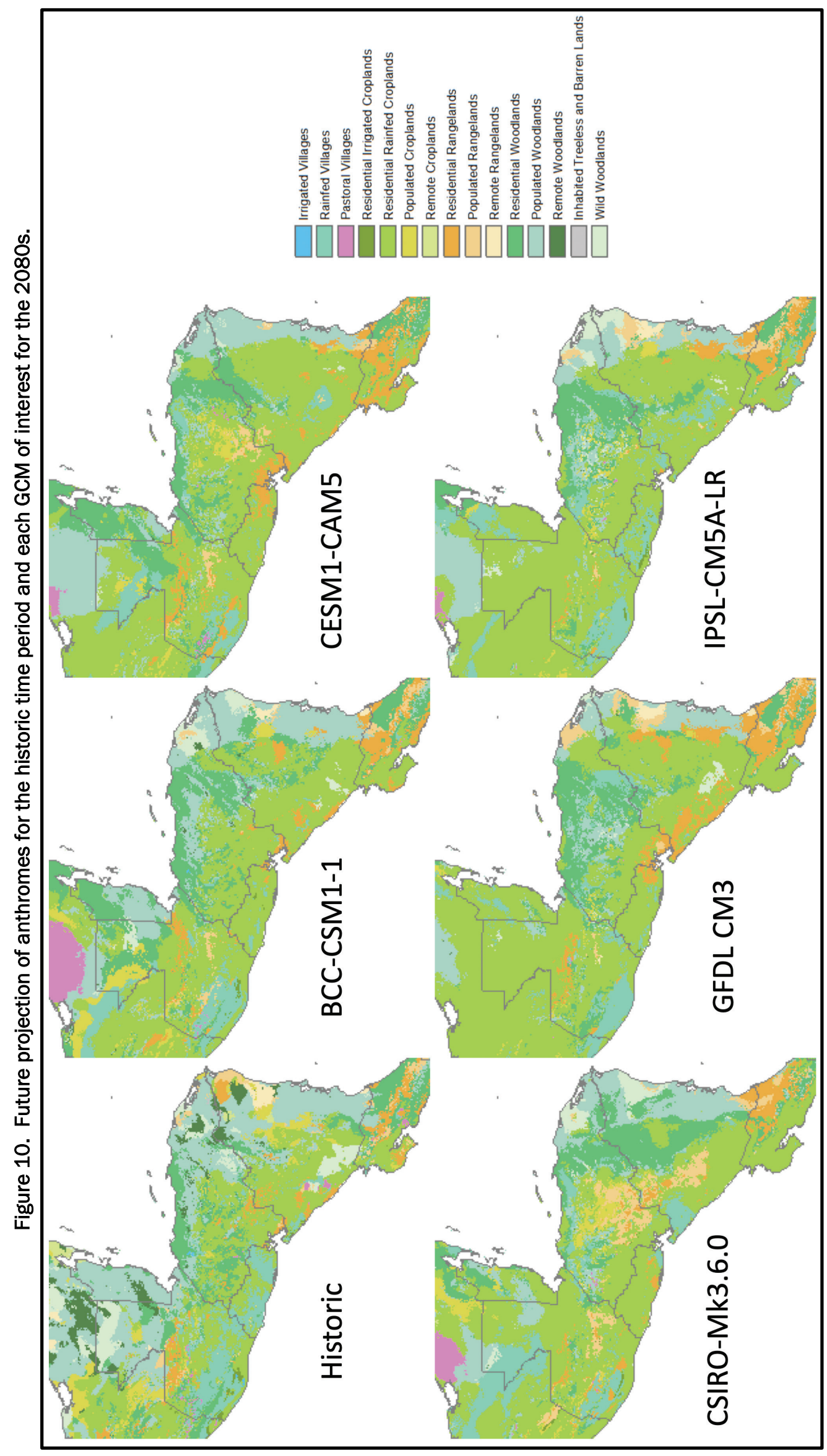


Table 9. Historic and future percent ranges and calculated percent decrease of rainfed villages.

\begin{tabular}{|l|c|c|c|}
\hline Country & Historic $\%$ & Future $\%$ & $\%$ Change \\
\hline Belize & 0 & 0 to 25 & 0 to 25 \\
\hline Guatemala & 19 & 15 & -4 \\
\hline Honduras & 3 & - & - \\
\hline El Salvador & 55 & 4 to 30 & -25 to -51 \\
\hline Nicaragua & - & - & - \\
\hline
\end{tabular}

\subsubsection{Residential rainfed croplands - rainfed cropland with substantial human populations}

All of the countries of interest in Central America show an increase for at least one GCM for residential rainfed croplands. Belize increases from o\% as residential rainfed cropland in the historic time period, to ranging between $5 \%$ and $83 \%$ coverage. Guatemala has a range of GCMs between $45 \%$ and $77 \%$ in the future compared to $\sim 28 \%$ for the historic time period, leading to a percent difference of an increase between $60 \%$ and $180 \%$. Honduras has a historic percent coverage of $32 \%$ while future projections range between $30 \%$ and $45 \%$, which is a change of $-2 \%$ to $13 \%$. Nicaragua sees both an increase and decrease from $34 \%$ coverage during the historic time period to $30 \%$ to $60 \%$ coverage in the future, which is a difference between $-4 \%$ and $26 \%$. As with the other Central American countries, El Salvador increases in coverage of residential rainfed croplands from the historic time period at $42 \%$ to the future projection at $65 \%$ to $90 \%$, which is a change of $23 \%$ to $48 \%$. Table 10 summarizes percent ranges of residential rainfed croplands.

Table 10. Historic and future percent ranges and calculated percent decrease of residential rainfed croplands.

\begin{tabular}{|l|c|c|c|}
\hline Country & Historic $\%$ & Future $\%$ & $\%$ Change \\
\hline Belize & 0 & 5 to 83 & 5 to 83 \\
\hline Guatemala & 28 & 45 to 77 & 17 to 49 \\
\hline Honduras & 32 & 30 to 45 & -2 to 13 \\
\hline El Salvador & 42 & 65 to 90 & 23 to 48 \\
\hline Nicaragua & 34 & 30 to 60 & -4 to 26 \\
\hline
\end{tabular}




\subsubsection{Residential rangelands - rangelands with livestock grazing and minimal forests and crops with substantial human populations}

Nicaragua had a minimal amount of residential rangeland, historically at $\sim 5 \%$. Future projections exhibit a range of residential rangeland from $3 \%$ to $15 \%$, which is a changes between $-2 \%$ and $10 \%$ in the future. El Salvador had nearly $0 \%$ coverage as residential rangeland for the historic period and is projected to have between $0 \%$ and $15 \%$ in the future. This is a percent change between $-1 \%$ and $14 \%$ between historic and future percentages. Table 11 summarizes percent ranges of residential rangelands.

Table 11. Historic and future percent ranges and calculated percent decrease of residential rangelands.

\begin{tabular}{|l|c|c|c|}
\hline \multicolumn{1}{|c|}{ Country } & Historic $\%$ & Future $\%$ & $\%$ Change \\
\hline Belize & 0 & - & - \\
\hline Guatemala & 5 & - & - \\
\hline Honduras & 3 & - & - \\
\hline El Salvador & 1 & 0 to 15 & -1 to 14 \\
\hline Nicaragua & 5 & 3 to 15 & -2 to 10 \\
\hline
\end{tabular}

\subsubsection{Residential woodlands - forests with substantial human populations}

Compared to historic values for residential woodlands across Central America, some countries and some GCMs will experience a decrease in residential woodlands in the future, while others will experience an increase; there is a lack of consistency in regard to future projections. Belize has a historical amount of $5 \%$, but in the future will range from $3 \%$ to $60 \%$ coverage of residential woodlands. This is a change in percentage between $-2 \%$ and $55 \%$. Guatemala will experience a similar pattern, of having both an increase and decrease. Historically, about $11 \%$ of Guatemala's land has been residential rangeland; in the future, it is projected to have between $3 \%$ and $15 \%$, which is a percentage change between $-8 \%$ and $4 \%$. Similarly, Honduras will also continue the trend of having some increase and decrease from historic values. For the historic time period, Honduras has had $23 \%$ coverage as residential rangeland. However, in the future, its coverage will range from $20 \%$ to $30 \%$, which is a percentage change between $-3 \%$ and $7 \%$. All future projections show that Nicaragua will increase from about $4 \%$ for its historic period to between $5 \%$ and $25 \%$. This is a percentage change between $-1 \%$ and $21 \%$. Table 12 summarizes percent ranges of residential woodlands. 
Table 12. Historic and future percent ranges and calculated percent decrease of residential woodlands.

\begin{tabular}{|l|c|c|c|}
\hline Country & Historic $\%$ & Future $\%$ & $\%$ Change \\
\hline Belize & 5 & 3 to 60 & -2 to 55 \\
\hline Guatemala & 11 & 3 to 15 & -8 to 4 \\
\hline Honduras & 23 & 20 to 30 & -3 to 7 \\
\hline El Salvador & 1 & - & - \\
\hline Nicaragua & 4 & 5 to 25 & -1 to 21 \\
\hline
\end{tabular}

\subsubsection{Populated woodlands - forests with minor human populations}

All countries and all GCMs exhibit a decrease in populated woodlands from the historic time period to the future projections. Belize decreases from $83 \%$ for the historic period to between $1 \%$ and $48 \%$ coverage of populated woodlands for the future, which is a percentage change of $-35 \%$ to $-82 \%$. Historically Honduras started at $29 \%$ but dropped to $15 \%$ to $22 \%$, which is a percentage change of $-7 \%$ to $-14 \%$. Nicaragua also decreased from historic values at $32 \%$ to projected values at $15 \%$ to $28 \%$, which is a change of $-4 \%$ to $17 \%$. Table 13 summarizes percent ranges of populated woodlands.

Table 13. Historic and future percent ranges and calculated percent decrease of populated woodlands.

\begin{tabular}{|l|c|c|c|}
\hline Country & Historic $\%$ & Future $\%$ & $\%$ Change \\
\hline Belize & 83 & 1 to 48 & -35 to -82 \\
\hline Guatemala & 22 & - & - \\
\hline Honduras & 29 & 15 to 22 & -7 to -14 \\
\hline El Salvador & 1 & - & - \\
\hline Nicaragua & 32 & 15 to 28 & -4 to -17 \\
\hline
\end{tabular}

\subsection{Combined crop suitability and human settlement}

After analyzing each crop individually, the crops were combined to create an overall projected change in land suitability map (Figure 11). To determine overall land suitability change, the maps were aggregated to provide a rough idea of where there is likely to be an increase or decrease in crop suitability. Note that the scale represents the amount of agreement between models. This map is a summary of the general suitability of the crops studied in this report and is not necessarily a representation of suitability for each specific crop. The green areas represent areas that are likely to become more suitable, while the red represents areas likely to become 
less suitable. A designation of "o" represents "no change" and is almost exclusively representative of lands that are not cropped in the baseline model or that are designated biological preserves. The -4 to 4 designation represents the range of agreement/disagreement between the GCM's that change will improve or worsen suitability for crops.

The northern part of the Guatemala and about half of Belize will become less suitable for crop growth. However, the southern part of Guatemala, most of El Salvador, and the western part of Honduras will become more suitable for crop growth. By contrast, the central portion of Honduras is likely to become less suitable, and has the highest agreement of the models to be the least suitable location of crop growth throughout all of Central America. Nicaragua is a mix of becoming less suitable and more suitable, with locations near the coast likely becoming less suitable and inland locations becoming more suitable.

Figure 11. Overall projected change in land suitability from the four GCMs under scenario A2. Note that the scale represents the amount of agreement between models.

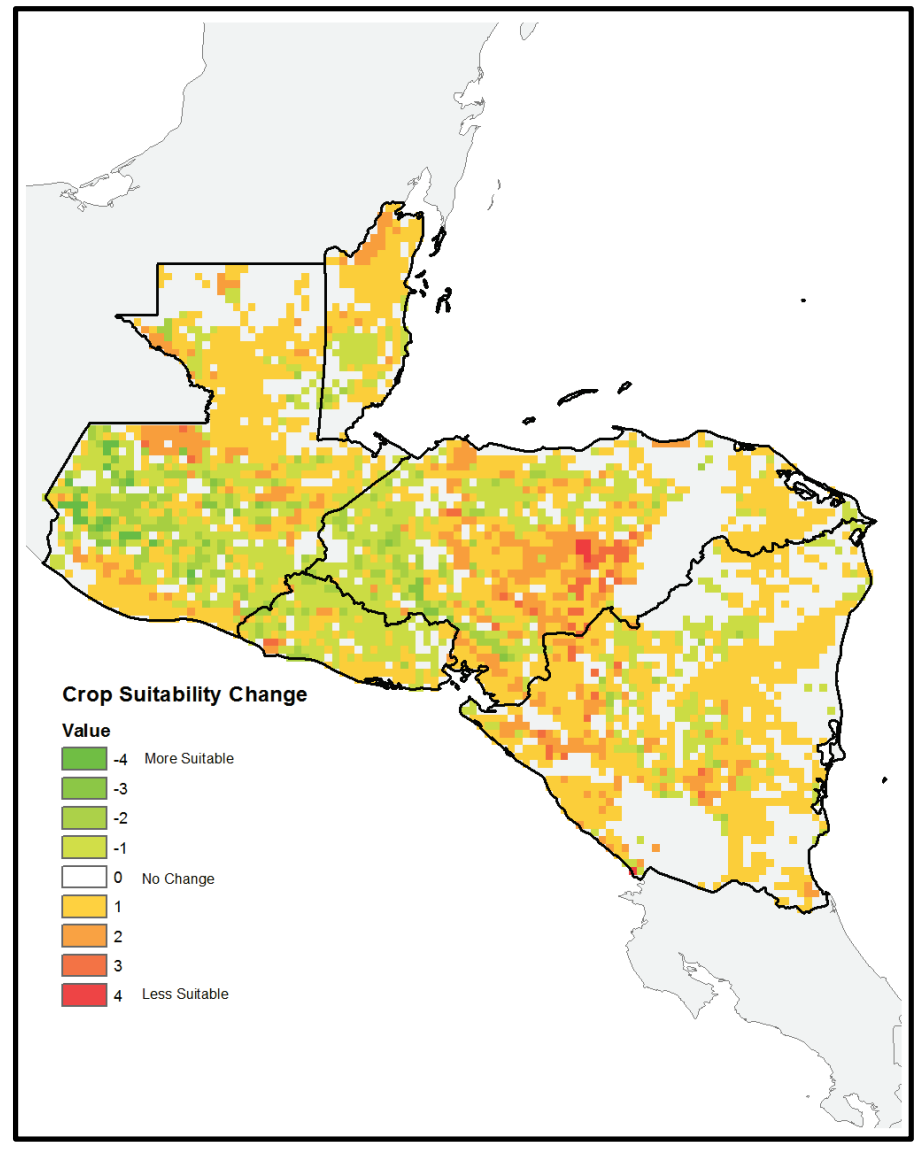


All of the future anthrome projections were combined to create a map representing the most likely occurrence of anthromes in the future. This was done by using the Cell Statistics tool in ArcGIS and determining the majority type of anthrome per pixel. Therefore, the different anthromes represented in Figure 12 part B is the anthrome that occurs most frequently among the future GCMs at that pixel location. Once again the region is dominated by residential rainfed croplands. The east coast of Honduras and Nicaragua has areas of populated woodlands and parts of the west coast of Guatemala has some rainfed villages.

For comparative purposes, Figure 12 part A shows historic anthromes. In general, the trends of anthrome locations remain the same from the historic period to the future. The anthrome change analysis suggests an increase in land area classified as residential rainfed cropland and shows a reduction in nearly every other anthrome including populated woodlands and rainfed villages. However, for both historic and future projections, much of the area is dominated by residential rainfed croplands along with some populated woodlands and residential woodlands dominating the east coast. 


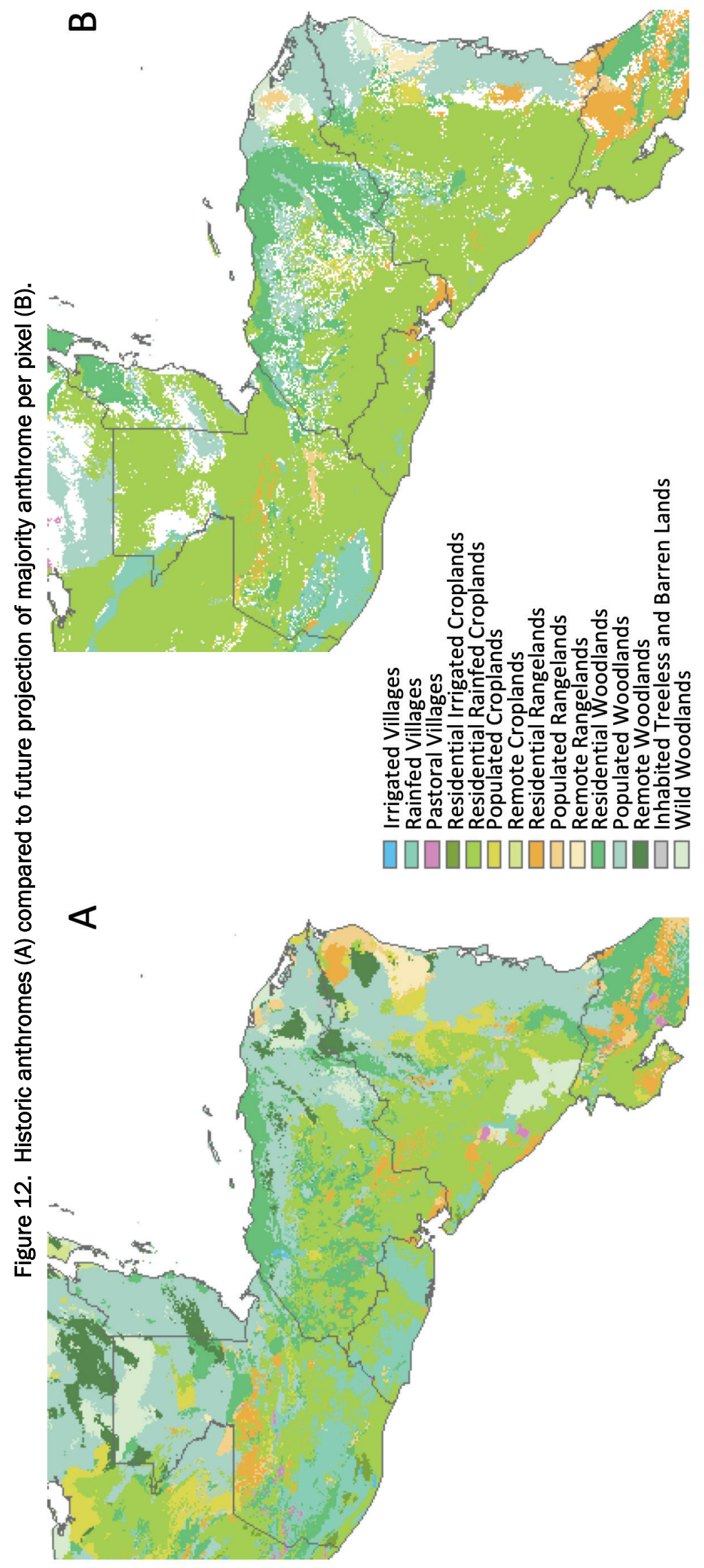




\section{Discussion and Conclusions}

Probable shifts in crop suitability and anthromes are likely to impact numerous aspects of the Central American region. It is possible that a full suite of downscaled models may produce a wider range of results than suggested here. Nonetheless, the methodology of using downscaled models in the current analysis allows planners to visualize the scale of potential effects of projected environmental changes on populations, and to begin to assess potential impacts that, as time goes on, should be possible to verify.

In general, Central America cropland will become less suitable for the primary crops currently grown there (Figure 11). However, it is important to note that the land may still be suitable to grow crops; it will just become less suitable compared to current conditions. While these trends are variable among the five countries in question, the results of this analysis indicate that change is expected to most affect central Honduras and west Nicaragua. In these countries, land that is currently considered suitable for these crops is expected to become less suitable for production of those crops.

However, even though the land may become less suitable for the crop that is currently growing there, it may become more suitable for different crops. For example, if the area is likely to experience less rainfall, a crop that is less dependent on rain may thrive there. Additionally, other agricultural modifications could be made to enable crops to better accommodate future climates, e.g., by installing systems of irrigation or by changing planting dates.

Changes in future climates are likely to have many impacts on food security in the Central American region. If crops cannot be grown due to changing climatic conditions, there will likely be a shift in population. People need access to food and water to survive; if those needs cannot be met, they will migrate. This will likely force people out of rural environments and into urban areas, an effect known as urban migration.

The initial stress, of finding sufficient food and water, that initiates migration can further be compounded with the additional stresses of finding adequate housing and jobs in the urban environment. The movement of large numbers of people to a new location can strain that new location's existing 
infrastructure and economy, resulting in a stressful living environment that can increase the chances of political unrest, especially in politically tumultuous areas, and increase the odds of people joining rebel groups and political insurgencies.

Visually, there is some agreement between the anthrome projections and the projected cropland suitability. However, it is important to note that a decrease in crop suitability does not mean that land is not suitable for crop production, only that it is expected to be less suitable than it is currently for that crop, or that it may be better suited for another crop. Similarly, the fact that land may remain or change to residential rainfed croplands (or any other anthrome), may not mean that crop production will increase (or decrease); it means only that, based on historic bioclimatic indices, this area is likely to experience this anthrome with anticipated future climates.

We also note that the projection of future anthromes based on changing bioclimatic indices alone neglects other influences on the population.

Other influences could include, for example:

- changing agricultural practices and other technologic advances (e.g., genetically modified crops, irrigation availability)

- changes to population structure

- the presence of infrastructure and changes to it (e.g., roads, ports); culture (e.g., language, history); and societal structures (e.g., land ownership, government, universities, economic development and external financial incentives), which might encourage a population to remain in place despite changing environmental conditions.

Our analysis does not attempt to address these influences, but rather attempts to answer the question "In what direction will environmental factors alone be likely to influence human populations as they are currently structured?" Clearly all of these influences are likely to be significant, and in many instances can be more significant than any environmental factors alone. Future works include expanding this analysis into the Philippines and examining different future climate pathways. 


\section{References}

Alexandratos, Nikos, and Jelle Bruinsma. 2012. World Agriculture towards 2030/2050. Food and Agriculture Organization of the United Nations. http://www.fao.org/3/aap106e.pdf.

Asseng, S., F. Ewert, P. Martre, R. P. Rötter, D. B. Lobell, D. Cammarano, B. A. Kimball, M. J. Ottman, G. W. Wall, J. W. White, M. P. Reynolds, P. D. Alderman, P. V. V. Prasad, P. K. Aggarwal, J. Anothai, B. Basso, C. Biernath, A. J. Challinor, G. De Sanctis, J. Doltra, E. Fereres, M. Garcia-Vila, S. Gayler, G. Hoogenboom, L. A. Hunt, R. C. Izaurralde, M. Jabloun, C. D. Jones, K. C. Kersebaum, A-K. Koehler, C. Müller, S. Naresh Kumar, C. Nendel, G. O’Leary, J. E. Olesen, T. Palosuo, E. Priesack, E. Eyshi Rezaei, A. C. Ruane, M. A. Semenov, I. Shcherbak, C. Stöckle, P. Stratonovitch, T. Streck, I. Supit, F. Tao, P. J. Thorburn, K. Waha, E. Wang, D. Wallach, J. Wolf, Z. Zhao, and Y. Zhu. 2015. "Rising Temperatures Reduce Global Wheat Production." Nature Climate Change 5:143-147. https://doi.org/10.1038/nclimate2470.

Bassu, Simona. Nadine Brisson, Jean-Louis Durand, Kenneth Boote, Jon Lizaso, James W. Jones, Cynthia Rosenzweig, Alex C. Ruane, Myriam Adam, Christian Baron, Bruno Basso, Christian Biernath, Hendrik Boogaard, Sjaak Conijn, Marc Corbeels, Delphine Deryng, Giacomo De Sanctis, Sebastian Gayler, Patricio Grassini, Jerry Hatfield, Steven Hoek, Cesar Izaurralde, Raymond Jongschaap, Armen R. Kemanian, K. Christian Kersebaum, Soo-Hyung Kim, Naresh S. Kumar, David Makowski, Christoph Müller, Claas Nendel, Eckart Priesack, Maria Virginia Pravia, Federico Sau, Iurii Shcherbak, Fulu Tao, Edmar Teixeira, Dennis Timlin, and Katharina Waha. 2014. "How Do Various Maize Crop Models Vary in Their Responses to Climate Change Factors?” Global Change Biology 20:23012320. https://doi.org/10.1111/gcb.12520.

Bernstein, L., P. Bosch, O. Canziani, Z. Chen, R. Christ, O. Davidson, W. Hare, S. Huq, D. Karoly, V. Kattsov, Z. W. Kundzewicz, J. Liu, U. Lohmann, M. Manning, T. Matsuno, B. Menne, B. Metz, M. Mirza, N. Nicholls, L. Nurse, R. Pachauri, J. Palutikof, Palutikof, M. Palutikof, D. Qin, N. H. Ravindranath, A. Reisinger, Reisinger, J. Reisinger, K. Riahi, C. Rosenzweig, M. Rusticucci, S. Schneider, Y. Sokona, S. Solomon, P. Stott, R. Stouffer, T. Sugiyama, R. J. Swart, D. Tirpak, C. Vogel, and G. Yohe. 2008. Climate Change 2007: Synthesis Report: An Assessment of the Intergovernmental Panel on Climate Change. Paris, France: Intergovernmental Panel on Climate Change. http://edepot.wur.nl/62320.

Bernstein, L., P. Bosch, O. Canziani, Z. Chen, R. Christ, O. Davidson, W. Hare, S. Huq, D. Karoly, V. Kattsov, Z. W. Kundzewicz, J. Liu, U. Lohmann, M. Manning, T. Matsuno, B. Menne, B. Metz, M. Mirza, N. Nicholls, L. Nurse, R. Pachauri, J. Palutikof, M. Parrry, D. Qin, N. H. Ravindranath, A. Reisinger, J. Ren, K. Riahi, C. Rosenzweig, M. Rusticucci, S. Schneider, Y. Sokona, S. Solomon, P. Stott, R. Stouffer, T. Sugiyama, R. J. Swart, D. Tirpak, C. Vogel, and G. Yohe. 200o. IPCC Special Report on Emissions Scenarios: Summary for Policymakers Emissions Scenarios. Geneva, Switzerland: Intergovernmental Panel on Climate Change (IPCC). https://www.ipcc.ch/pdf/special-reports/spm/sres-en.pdf. 
Ellis, E. C., and N. Ramankutty. 2008. "Putting People in the Map: Anthropogenic Biomes of the World." Frontiers in Ecology and the Environment 6(8):439-447. https://doi.org/10.1890/070062.

FAO (Food and Agriculture Organization of the United Nations). 2017. FAOSTAT. Rome, Italy: FAO. http://www.fao.org/faostat/en/\#data.

IIASA/FAO (International Institute for Applied Systems Analysis/Food and Agriculture Organization of the United Nations). 2012. GAEZ: Global Agro-Ecological Zones (GAEZ v3.0). Laxenburg, Austria: IIASA, and Rome, Italy: FAO. http://gaez.fao.org/Main.html\#.

Jarvis, A. 2014. “Spatial Downscaling Data." GCM Downscaled Data Portal. http://-climate.org/data_spatial_downscaling/.

Liaw, Andy, and Matthew Wiener. 2002. "Classification and Regression by RandomForest.” R News Vol. 2/3, December 2002. https://www.researchgate.net/publication/228451484.

Martin, Laura J., John E. Quinn, Erle C. Ellis, M. Rebecca Shaw, Monica A. Dorning, Lauren M. Hallett, Nicole E. Heller, Richard J. Hobbs, Clifford E. Kraft, Elizabeth Law, Nicole L. Michel, Michael P. Perring, Patrick D. Shirey, and Ruscena Wiederholt. 2014. "Conservation Opportunities across the World's Anthromes." Diversity and Distributions 20(7):745-755. https://doi.org/10.1111/ddi.12220.

O’Donnell, M. S., and D. A. Ignizio. 2012. Bioclimatic Predictors for Supporting Ecological Applications in the Conterminous United States. U.S Geological Survey (USGS) Data Series 691. Reston, VA: USGS. https://pubs.usgs.gov/ds/691/ds691.pdf.

Ramirez, J., and A. Jarvis. 2008. High Resolution Statistically Downscaled Future Climate Surfaces. Cali, Colombia: International Center for Tropical Agriculture (CIAT); CGIAR Research Program on Climate Change, Agriculture and Food Security.

Riahi, K., S. Rao, V. Krey, C. Cho, V. Chirkov, G. Fischer, G. Kindermann, N. Nakicenovic, and R. Rafaj. 2011. "RCP 8.5-A Scenario of Comparatively High Greenhouse Gas Emissions." Climatic Change 109(1-2):33-57. 10.1007/s10584-011-0149-y. 


\section{Acronyms and Abbreviations}

$\begin{array}{ll}\text { Term } & \text { Definition } \\ \text { CAMP } & \text { Climate Adaptive Mission Planning } \\ \text { CERL } & \text { Construction Engineering Research Laboratory } \\ \text { CSV } & \text { Comma-Separated Values } \\ \text { ERDC } & \text { U.S. Army Engineer Research and Development Center } \\ \text { ESRI } & \text { Environmental Systems Research Institute } \\ \text { FAO } & \text { Food and Agriculture Organization of the United Nations } \\ \text { GAEZ } & \text { Global Agro-Ecological Zone } \\ \text { GCM } & \text { Global Circulation Model } \\ \text { GDP } & \text { Gross Domestic Product } \\ \text { GHG } & \text { Greenhouse Gas } \\ \text { GIS } & \text { Geographic Information System } \\ \text { IIASA } & \text { International Institute for Applied Systems Analysis } \\ \text { IPCC } & \text { Intergovernmental Panel on Climate Change } \\ \text { NetCDF } & \text { Network Common Data Form } \\ \text { RCP } & \text { Representative Concentration Pathway } \\ \text { SRES } & \text { The Special Report on Emissions Scenarios } \\ \text { TR } & \text { Technical Report }\end{array}$




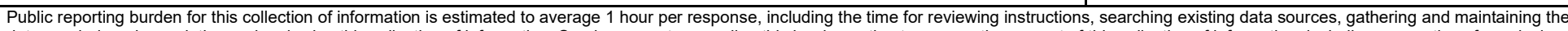

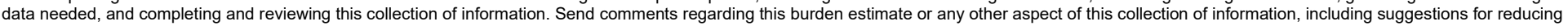

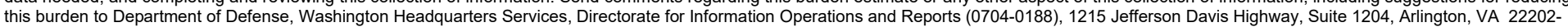

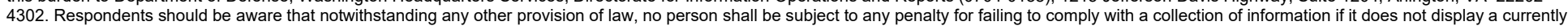
valid OMB control number. PLEASE DO NOT RETURN YOUR FORM TO THE ABOVE ADDRESS.
1. REPORT DATE (DD-MM-YYYY)
$05 / 01 / 20$
2. REPORT TYPE
Final Technical Report (TR)

\section{TITLE AND SUBTITLE}

Projecting Changes in Food Security Throughout Central America
3. DATES COVERED (From - To)

5a. CONTRACT NUMBER

\section{5c. PROGRAM ELEMENT}

\section{AUTHOR(S)}

Kayla A. Cotterman, Aaron C. Petri, James D. Westervelt, and Angela M. Rhodes

\section{5d. PROJECT NUMBER}

\section{5e. TASK NUMBER}

\section{5f. WORK UNIT NUMBER}

\section{PERFORMING ORGANIZATION NAME(S) AND ADDRESS(ES)}

U.S. Army Engineer Research and Development Center (ERDC)

Construction Engineering Research Laboratory (CERL) 2905 Newmark Dr.

Champaign, IL 61824

Coastal and Hydraulics Laboratory (CHL) 3909 Halls Ferry Road

Vicksburg, MS 39180

ERDC TR-20-11

\section{PERFORMING ORGANIZATION REPORT NUMBER}

10. SPONSOR/MONITOR'S ACRONYM(S)

\section{SPONSORING / MONITORING AGENCY NAME(S) AND ADDRESS(ES)}

Headquarters, U.S. Army South 2450 Stanley Road, Building 1000

Fort Sam Houston, Texas 78234

11. SPONSOR/MONITOR'S REPORT NUMBER(S)

\section{DISTRIBUTION / AVAILABILITY STATEMENT}

Approved for public release; distribution is unlimited.

\section{SUPPLEMENTARY NOTES}

This work was funded via Funding Authorization Document (FAD) 2040-19/20-40, "Risk Assessment Planning and Tools for Operations" (RAPTOR), Project No. 477345-T222, "Human Geography."

\section{ABSTRACT}

Climate non-stationarity continues to change the productivity of local food and water supply. These changes in supplies could result in starvation or surpluses, greatly affecting the surrounding populations and causing adverse effects such as malnutrition, mass migration, and political unrest. This study addresses the following questions regarding the future potential of land resources to support local populations with food and water: How will crop production be affected by changing environmental conditions? Which specific regions are expected to experience the greatest pressure? How might we expect land use to shift through the end of the 21st century, based on future environmental conditions? Current crop growth is analyzed, along with projected crop growth based on future climate scenarios. Recent historic anthropogenic biome maps are statistically correlated with recent historic climate data to generate models and are applied to anticipated future climates to generate future anthrome maps. The crop analysis is then coupled with the anthromes results, yielding a crop suitability forecast. This analysis is constrained to the area of Central America over the course of the 21st century for this study.

\section{SUBJECT TERMS}

Climatic changes--Forecasting, Crops--Growth, Food supply, Land use, Water-supply, Central America

\begin{tabular}{|c|c|c|c|c|c|}
\hline \multicolumn{3}{|c|}{ 16. SECURITY CLASSIFICATION OF: } & \multirow{2}{*}{$\begin{array}{l}\text { 17. LIMITATION } \\
\text { OF ABSTRACT } \\
\text { SAR }\end{array}$} & \multirow{2}{*}{$\begin{array}{l}\text { 18. NUMBER } \\
\text { OF PAGES }\end{array}$} & 19a. NAME OF RESPONSIBLE PERSON \\
\hline $\begin{array}{l}\text { a. REPORT } \\
\text { Unclassified }\end{array}$ & $\begin{array}{l}\text { b. ABSTRACT } \\
\text { Unclassified }\end{array}$ & $\begin{array}{l}\text { c. THIS PAGE } \\
\text { Unclassified }\end{array}$ & & & $\begin{array}{l}\text { 19b. TELEPHONE NUMBER } \\
\text { (include area code) }\end{array}$ \\
\hline
\end{tabular}

